\title{
Güçlendirme ve Toplumsal Cinsiyet Rolleri İkileminde Kadın Girişimciliği
}

\author{
Aslican KALFA TOPATEŞ1 \\ ORCID: 0000-0002-0790-6150
}

Hakan TOPATEŞ 2

ORCID: 0000-0002-1344-6509

Erkan KIDAK ${ }^{3}$

ORCID: 0000-0001-5856-5686

DOI: $10.54752 /$ ct.1061145

\begin{abstract}
Öz: 1970'li yıllardan itibaren sosyal refah devleti uygulamalarının terk edilmesi ve işçi-işveren-devlet arasındaki konsensüsün ekonomipolitik olarak dönüşmesiyle birlikte yoksulluk ve işsizlik oranlarında ciddi artışlar yaşanmıştır. Akışkan küresel sermayeye ucuz işgücü sağlayan neoliberal politikalar, emeğin feminizasyonuna ve kadın yoksulluğunun derinleşmesine yol açmıştır. Bu kaotik çerçevede kadınların karşı karşıya kaldıkları ekonomik ve sosyal sorunlara yönelik farklı kalkınma yaklaşımları ortaya çıkmıştır. Kadınların girişimci statüsünde istihdama dâhil olmasına yönelik geliştirilen ulusal ve uluslararası düzeydeki programlarda güçlendirme yaklaşımı ön planda yer almaya başlamıştır. Bu noktada güçlendirme yaklaşımı ile girişimcilik olgusu arasında bir kesişimsellik oluşmuştur. Öte yandan ataerkil kapitalist sisteme içkin olan toplumsal cinsiyet rolleri çerçevesinde eril bir anlam atfedilen girişimcilik, kadın yoksulluğunun önlenmesinde bir sosyal politika aracı olarak görülmüştür. Ancak kadınların piyasalardan kaynaklanan risklere karşı sorumluluk alarak
\end{abstract}

${ }^{1}$ Dr. Öğr. Üyesi, Pamukkale Üniversitesi İ̈BF Çalışma Ekonomisi ve Endüstri İlişkileri Bölümü- aslicankalfa@gmail.com

${ }^{2}$ Dr. Öğr. Üyesi, Pamukkale Üniversitesi İ̈BF Çalışma Ekonomisi ve Endüstri İlişkileri Bölümü- hakantopates@gmail.com

3 Ar. Gör., Pamukkale Üniversitesi İIBF Çalışma Ekonomisi ve Endüstri İlişkileri Bölümükidakerkan@gmail.com

Kalfa Topateş, A, Topateş, H. ve Kıdak, E. (2022). “Güçlendirme ve Toplumsal Cinsiyet Rolleri İkileminde Kadın Girişimciliği” Çalışma ve Toplum, C.2, S.73. s.1043-1074.

Makale Geliş Tarihi: 08.10.2021 - Makale Kabul Tarihi:13.12.2021 
kendi hesabına çalışmaları veya işveren olabilmeleri, bütünsel ve kapsayıc1 bir sosyal politika uygulamasindan ziyade bireysel/geçici/tikel bir çözüm niteliğinde görülebilir. Güçlendirme olgusu bağlamında bu çözümler kadınları bireysel düzeyde özgürleştirebilse de ataerkil kapitalizmin yapısal koşullarının yeniden üretiminin engellenmesi mümkün görünmemektedir. Oysaki kadınların toplumsal özgürleşmesi, sosyal refah devleti uygulamalarıyla toplumsal cinsiyet eşitliği perspektifinin bütünleşeceği bir sosyal politika yaklaşımı üzerinden gerçekleştirilebilir. Bu çalışmanın amacı da, emek sürecinde toplumsal cinsiyet, güçlendirme ve girişimcilik ilişkiselliğini ilgili literatürden hareketle kesişimsel bir perspektifle analiz etmektir.

Anahtar kelimeler: Kadın yoksulluğu, güçlendirme yaklaşımı, toplumsal cinsiyet, kadın girişimciliği, kalkınma

\section{Women's Entrepreneurship in the Dilemma of Empowerment} and Gender Roles

Abstract: Poverty and unemployment rates have dramatically increased by abandoning the social welfare state practices and transforming the consensus between employers, workers, and the state as a political economy since the 1970s. The neoliberal politics that provide cheap labor to liquid global capital has caused feminization of labor and deepening women's poverty. In this chaotic context, differentiating development approaches have emerged related to economic and social problems confronted by women. The empowerment approach has become prominent in national and international programs for women to generate employment as entrepreneurs. At this point, an intersectional sphere has emerged between the empowerment approach and the fact of entrepreneurship. On the other hand, entrepreneurship, which is attributed a masculine meaning within the framework of gender roles inherent in the patriarchal capitalist system, has been seen as a social policy tool in the prevention of women's poverty. However, the fact that women are working as self-employed or becoming employers by taking on responsibility against risks resulted from markets can be seen as an individual/temporary/particular solution rather than holistic and inclusive social policy practices. In the context of the empowerment approach, even if these solutions can liberate women at the individual level, it does not seem possible to prevent the reproduction of the structural conditions of patriarchal capitalism. Thus, women's social emancipation can be realized by using the social policy approach integrating the perspective of gender equality and practices of the social welfare state. The aim of this research, in which 
the literature review method is used, is to analyze the relationality of gender, empowerment, and entrepreneurship in the labor process through an intersectional perspective.

Keywords: Women's poverty, empowerment approach, gender, women entrepreneurship, development

\section{Giriş}

Girişimcilik, sosyal dayanışma ve evrenselcilik prensipleriyle temellenen sosyal refah devletinin zayıflamasıyla ve işçi-şsveren-devlet arasındaki sosyal politika konsensüsünün ekonomi-politik olarak dönüşmesiyle birlikte, 1970'li ylllardan itibaren artan yoksulluk ve işsizliğe karşı bir önlem olarak Avrupa Birliği tarafindan desteklenmiştir. Bu süreçte girişimcilik özellikle Dünya Bankası ve Birleşmiş Milletler gibi uluslararası kuruluşlarca geliştirilen kalkınma programları dâhilinde gelişmekte olan ülkelere sosyo-ekonomik bir reçete olarak sunulmuştur. Kadın yoksulluğuna bir çözüm arayışı olarak tasarlanan ve uygulanan girişimcilik ${ }^{4}$ olgusu, üretim faktörlerinin bir araya getirilmesi suretiyle hayata geçirilen bireysel ticari faaliyetler olarak tanımlanabilir.

Kadın girişimciliği ise, yoksulluğun ve işsizliğin giderek kadınlaşmasına yönelik cinsiyet duyarlı kalkınma perspektifi doğrultusunda bir çare olarak düşünülmüştür. Kadın girişimci kavramı, işletmesinde piyasa risklerini üstlenerek kendi hesabına çalışan ya da istihdam yaratan kadınlan tanımlamak için kullanılmaktadır (Soysal, 2010: 90). Kadınların girişimciliğe dair pratikleri aynı zamanda içinde yaşadıkları toplumun bir yansımasıdır (McAdam, 2013: 8). Bu anlamda kadın girişimciliğinin çok boyutlu bir içeriğe sahip olduğu ve formel yapısının üzerinde farklılaşan ekonomik ve kültürel etkilerin bulunduğu belirtilmelidir (2013: 8). Girişimciliğin toplumsal cinsiyetle olan ilişkiselliği, 1970’li yıllarda ikinci dalga feminizmin yükselişe geçmesiyle birlikte popülerleşmiştir. Bu kapsamda girişimciliğin farklı kültürlerden nasıl etkilendiği, işgücü piyasasında yaşanan ayrımcılık pratikleri ve toplumsal cinsiyet eşitliği politikaları gibi konular tartışılmıştır. Böylelikle güçlendirme ve kadın-erkek eşitliğine odaklanan çalışmalar, kadınların kalkınma politikalarındaki görünürlügünü artırmıştır (Sallan Gül ve Altındal, 2016: 1364).

Girişimcilik, sosyoloji, ekonomi, sosyal antropoloji, psikoloji gibi birçok farklı disiplinin ilgi odağı olmuştur. Psikolojik araştırmalar, bireysel etmenlerin girişimcilik

\footnotetext{
${ }^{4}$ Girişimcilik Schumpeter (1934, aktaran De Bruin vd. 2006: 586) tarafindan "yeni ürünler ve pazarlar, yeni dağıtım sistemleri ve yeni bileşimlerin” bir araya getirilmesi; Kirzner (1985, aktaran De Bruin vd. 2006: 586) tarafından bilginin yeni firsatlar yaratmak amaçlı kullanımı olarak tanımlanmıştır. Girişimci (entrepreneur) sözcüğünün etimolojik kökeni Fransızcadaki “entreprendre” sözcügünden gelmektedir (Rani, 1996: 3).
} 
davranışlarını nasıl etkileyeceği ve güdüleyeceği ${ }^{5}$ üzerine odaklanırken, antropolojik çalışmalar girişimciliğe dair sosyokültürel kalıp ve inanışlar üzerinde temellenmiştir. Sözü edilen çeşitlilik kapsamında, bu çalşsmada cinsiyet-kalkınma ilişkiselliği, güçlendirme yaklaşımı ve toplumsal cinsiyet ekseninde kesişimsel bir perspektifle ele alınacaktır. "Güçlendirme" yaklaşımı, bu bakış açısının geliştirilmesi kapsamında araştırmanın analiz çerçevesi olarak alınmıştır. Bu bağlamda, Arendt'in (2014: 305) özgürlügün bireylerin "başlama kapasiteleriyle özdeş" olduğunu belirtmesi, kadın özgürlüğü ve güçlenme arasındaki ilişkiselliğe 1şık tutması açısından anlamlıdır. Fakat bir yandan Horkheimer'ın (2012: 280) belirttiği gibi kadınların modernitede özgürleştiği zamanların tam da kapitalizmin yapısal işsizlik dönemine denk gelmesi, kadınların özgürleşmesinin önündeki engelleri çoğaltmaktadır.

Güçlendirme (empowerment) ve firsat (opportunity) kavramları, kadınların içinde yer aldıkları yapısallaşmış sosyo-ekonomik eşitsizliklerin minimize edilmesini sağlayan sosyal politika araçlarının tasarımında isslevsel olabilir. Bunun nedeni, firsat ve güçlendirme stratejilerine en fazla gereksinim duyanların işgücü piyasasında emek sömürüsüne maruz kalan kadınlar olmasıdır. Gerçekten de kadınların işgücü piyasasında ücretli emeğin sömürüye en açı, ucuz ve tehlikeye maruz kalan bölümünü oluşturmaları, kadın ve erkek işgücü arasında maddi bölünmenin doğmasina yol açmaktadır (Mackintosh, 1981: 7). Tam da bu noktada sermayenin kadınlar üzerindeki sömürü ilişkileri biçimlenmektedir. Kadının ev içi emeği üzerindeki patriyarkal denetim pratikleri, emek-sermaye ilişkilerinde yüksek düzeyde kârlılık yaratırken aynı zamanda mevcut üretim ilişkilerinin "güçlendirme" ve "firsat" stratejilerinin dişlandığ1 bir düzeyde sürmesinin güvencesini sağlamaktadır. Bu noktada sosyal politika uygulayıcılarının güçlendirme ve firsat bileşenleri kapsamında ikincil bir toplumsal statüye mahkûm edilen kadınları göz önünde bulundurması gerekmektedir (Nusbaum, 1999: 231). Bu araştırmanın temel motivasyonu da işgücü piyasaları kapsamında kadın emeği, güçlendirme ve kadın girişimciliğinin kesişimsel olarak incelenmesidir.

\section{Kalkınma Perspektifinde Güçlendirme Yaklaşımı ve Kadın Girişimciliği}

$\mathrm{Bu}$ bölümde kalkınma ekseninde toplumsal cinsiyet olgusu ve rolleriyle kadın girişimciliğinin kesişen bağlamları değerlendirilecektir. Fakat öncelikle büyük tarihçi Braudel'in (2015: 61) belirttiği, sosyal gerçekliklerin kapitalist sosyo-ekonomik formasyonun kendi bünyesinde yer alan alt ekonomilerin işleyişiyle anlaşılabileceği saptamasının bir analitik basamak olarak alınması gerekmektedir. İkinci olarak

5 Sarfaraz’a (2017: 37) göre toplumlarda kadın girişimciliğinin ekonomi-politik ve kültürel koşullarını üretecek bir sosyolojinin oluşmasında iş kurmaya dair motivasyonlar "zorunluluklar" ya da "firsatlar" yaratabilecektir. 
özellikle günümüz küresel zamanlarının belirgin sosyo-ekonomik dinamikleri açısından, Wallerstein'ın (2016: 34) değindiği anlamda kapitalizmin tarihsel fakat istikrarsız bozuklukları ancak meta zincirlerinin oluşturulması aracıllğıyla düzenlenmektedir ki bu devingen ekonomik ve politik regülasyonlar, Horkheimer'in (2013: 12) henüz 1956 yllında yeni biçimlerinin oluştuğunu söylemesinin üzerinden geçen "uzun yirminci yüzyllda" (Arrighi, 2016), yoksulluğun fazlaca farklılaşan boyutlarının da ortaya çıkmasına neden olmuştur. Özellikle kadın yoksulluğu bu paradigmanın en belirgin boyutunu göstermektedir. Tam da bu noktada birbirinden farklılaşan kalkınma yaklaşımlarına ve kalkınma olgusunun düzeylerine insan-merkezlilik perspektifinde değinilerek, güçlendirme yaklaşımının eşitlikçi içeriğine vurgu yapılacaktır. Fakat bir yandan da kadın girişimciliği pratiklerinin, küreselleşme çağında serbest piyasa ekonomilerinin metalaşma, sosyal dışlanma, proleterleşme ve nesneleşme üreten bağlamında, küresel yoksulluğun ve patriyarkal bariyerlerin minimize edilmesinde tek başına yeterli olmayan bir sosyal politika enstrümanı olduğu vurgulanacaktır.

\section{Toplumsal Cinsiyet Bağlamında Kalkınma Olgusu}

Kalkınma ve toplumsal cinsiyet ilişkisinin analitik olarak anlaşılabilmesi için kalkınma kavramının tanımlanması gerekmektedir:

"Kalkınma bir ülkede refahın artması, insanların sınıf, cinsiyet, etnik köken, din vb. farkı gözetilmeksizin insan onuruna yakışan bir yaşam düzeyi sürdürebilmesi için yürütülen çalışmalar olarak tanımlanabilir"” (Toksöz, 2011: 7).

Teorik, stratejik ve ideolojik olmak üzere üç temel düzeye sahip olan kalkınma (2011: 11), salt ekonomik değil toplumsal, bireysel, kültürel öğelerden oluşan bir süreçtir. $\mathrm{Bu}$ bağlamda kalkınmanın bireylerin yaşam koşullarının geliştirilmesi, ekolojik dengeyi bozmayan, toplumların kültürel farklılıklarını dikkate alan, kuşaklar ve cinsiyetler arasinda ayrımcllık ${ }^{6}$ yaratmayan, sosyal politika uygulamalarıla gelir dağılımı adaletsizliğini azaltan bir perspektifle anlaşılması gerekir.

İlgili literatürde kalkınma planları geleneksel olarak cinsiyet olgusuna duyarsız biçimde ele alınmış, kadınlar kalkınma plancıları tarafından "toplumsal hizmetlerin ve sağlık hizmetlerinin pasif yararlanıcıları olarak" değerlendirilmiştir. $\mathrm{Bu}$ noktada planlarda, kadının aktif ve üretken rolü göz ardı edilmiş, genellikle erkeklerin oluşturduğu toplumsal kesimler ya da meslekler odak noktası olarak belirlenmişsir (Moser, 1993: 2). Oysaki ülkelerin kalkınma düzeyleri aynı zamanda toplumsal cinsiyet eşitsizliğinin düzeylerini de sergilemektedir (Toksöz, 2011: 7). Ancak kalkınma düşüncesinin geçirdiği evrim, toplumsal cinsiyetin de bir kategori olarak sürece dâhil edilmesini içermiştir. Kalkınmada kadın teması, bağımlılık

\footnotetext{
${ }^{6}$ Wallerstein'a (2016: 88-89) göre cinsiyetçilik, insanlık tarihinde ilk kez kadının üretken emeğini üretken olmayan emek alanıyla sınırlandırmıştır.
} 
okulunun modernleşmeci teoriyi sarsması ve izleyen süreçte postmodern görüşlerin eleştirel yaklaşımı tarafindan biçimlendirilmiştir. Bu bağlamda modern teori "kalkınmada kadın", bağımlılık okulu "kalkınma ve kadın" yaklaşımlarının gelişmesini sağlarken, izleyen süreçte gelişen postmodern eleştiriler doğrultusunda "toplumsal cinsiyet ve kalkınma" yaklaşımı ortaya çıkmıştır (Toksöz, 2011: 48).7

Kalkınmanın "insan merkezliliği," ön plana çıkarılması açısından özellikle önem arz etmektedir. İnsan merkezli kalkınma yaklaşımı politik ve sivil özgürlüklerin yanı sıra kalkınma etiği kavramını kapsar. Kalkınma olgusu demokratik davranış biçimlerinin gelişmesini, toplumsal eşitliği, bireysel ve siyasal özgürlükleri içermektedir. Buna göre kalkınma, ekonomik gerekliliklerin yanı sıra insana özgü sosyal ilişkileri öne çıkararak kamusal alanı canlandırmalı, toplumlarda iletişimi ve kamusal kültürü geliştirmelidir. Habermas'ın (2019) "iletişimsel eylem kuramı" bağlamında değindiği, kamusal alan ve demokrasi arasındaki ilişkisellikler bu noktada değerlidir.

İnsan merkezli kalkınmada sağlık, eğitim, kültür, sosyal maliyetler ve kadının toplumsal konumunun iyileştirilmesi konularına ağırlık verilmektedir. Bununla birlikte küreselleşme süreçlerinin ve serbest piyasa ekonomisinin egemenliğinin etkisiyle insan merkezlilikten uzaklaşılması, bireylerin çalıssalar da yoksulluktan kurtulamadıkları, "yeni yoksulluk" olarak adlandırılan paradigmanın içine düşmeleri sonucunu doğurmaktadır. Yeni yoksulluk olgusuyla mücadele edebilmek amacıyla insan merkezlilik ekseninde firsat eşitliğini dengeli biçimde dağıtabilen, kadınları araçsallaştırmayan bir analitik yaklaşımın oluşturulması gerekmektedir. Bu noktada toplumsal cinsiyeti esas alan kalkınma yaklaşımı, kadınların kalkınmadaki potansiyel üretkenliğinin gerçekliğini gösterir. Ancak kalkınma çalışmalarında kimi işlevsel problemlerin bulunduğu da görülmektedir. Özellikle gelişmekte olan ülkelerde kadınların gereksinimleri yerel ve ulusal düzeyde karşıllı̆ını bulamamaktadır (Moser, 1993: 1-2). Kalkınma çalışmalarına dair bu tarz yapısal sorunların aşılması bağlamında Ostergaard'ın önerileri yol gösterici olabilir: Öncelikle kalkınma plancılarının etnosentrik önyargılar konusunda dikkatli olmaları gerekmektedir. İkinci olarak kalkınmanın çok yönlü bir süreç olması nedeniyle bürokratik-teknokratik bir yol yerine insan-merkezli bir perspektif benimsenmelidir. Üçüncü olarak kalkınmanın toplumsal cinsiyet boyutu kapsamında tüm nüfusu yansıtacak bütünsel bir analizin oluşturulması gerekir. Son olarak kalkınma yaklaşımlarının kültürel, toplumsal, ekonomik görünümlerine niceliksel ve niteliksel bir biçimde odaklanılmalıdır (Ostergaard, 1992: 1-10).

\footnotetext{
${ }^{7}$ Sözü geçen yaklaşımlarla ilgili ayrıntılı bilgi için bkz: (Toksöz, 2011: 52-62).

8 "İnsan merkezlilik" terimi, düşünce tarihinin ilk dönem filozoflarına kadar uzanmaktadır. Örneğin Sofizm'de, insanın bu dünyadaki ontik konumlanması, düşüncenin ve toplumun merkezine alınarak "homo-mensura" (insan her şeyin ölçütüdür) kavramıyla anlatılmıştır.

9 Yeni yoksulluk kavramıyla ilgili ayrıntılı bilgi için bkz: (Bauman, 1999). Alternatif bir kavramsallaştırma olarak derin yoksullukla ilgili ayrıntılı bilgi için bkz: (Derin Yoksulluk Ağı, 2020).
} 
İnsan merkezliliği dışlayan bir bakış açısı olarak iktisadi büyüme ve kalkınma ilişkisinde ekonomik büyümeyi sadece GSMH artışına göre değerlendiren yaklaşımların sınırlı ve palyatif olduğu görülmektedir. $\mathrm{Bu}$ perspektifte sosyal devletin ve firsat eşitliğinin gereği olarak milli gelirin tüm sosyal sınıflara dengeli bir biçimde dağıtılması gerekliliği ihmal edilmektedir. Örneğin büyüme merkezli kalkınma düşüncesine göre merkez-çevre ülkeler ilişkisinde azgelişmiş ülkelerin kalkınabilmesinin biricik yolu, finansal sermaye aktarımı ve uluslararası kuruluşlar öncülüğ̈̈nde merkezden çevreye kalkınma yardımları yapılması gerektiğidir. Böylelikle Wallersteinc1 (2014) anlamda küresel kapitalizmin bir "dünya sistemi olması" bağlamında, azgelişmiş ve gelişmekte olan ülkelerin kalkınmaları bir hakka ve eşitliğe dayanmak yerine lütuf olarak sunulmaktadır. Gerçekten de sanayileşmiş ülkelerin kalkınmayı manipülatif biçimde ve kendi çıkarları doğrultusunda kullanmalarıyla küreselleşme sürecinin gelişmiş ülkelerin lehine yapılandığ1 eşitsiz ilişkiler doğmaktadır (Şenses, 2004: 7). Neoliberalizm zamanlarında uluslararası finans kuruluşları aracıllğılyla, kalkınmacı bir perspektifin benimsenmesi mümkün görünmemektedir. Nitekim neoliberal küreselleşme, kalkınmanın önemli bir unsuru olan büyümeyi finansal sermaye hareketlerine terk ederken sinai üretimin yaygınlaştırılmasını güçleştirmektedir (2004: 18-19).

Toplumsal cinsiyet eşitsizliklerini gidermeye yönelik farklı perspektifler bağlamında toplumların ekonomik ve sosyo-kültürel gelişimini dizayn etmeye yönelik kalkınma süreçlerini içeren "refah yaklaşımı", "eşitlik yaklaşımı", "yoksulluk karşıtı yaklaşım", "verimlilik yaklaşımı" ve "güçlendirme yaklaşımı" olmak üzere beş yaklaşım geliştirilmiştir. Refah yaklaşımında kadınlar kalkınma sürecinin bir parçası olarak görülmeyerek sadece kalkınmanın pasif alııısı durumunda algılanırken, eşitlik yaklaşımında yeni modern teknolojilerin kadınları geleneksel üretken işlevlerinden uzaklaştırdığına değinilir. Yoksulluk karşıtı yaklaşımda amaç, kadın ve erkek arasındaki eşitsizliğin giderilmesi yerine gelir eşitsizliğinin azaltılmasıdır. Bu yaklaşımda pratik toplumsal cinsiyet gereksinimleri karşılanabilirken, stratejik toplumsal cinsiyet gereksinimleri açısından yetersizlikler bulunmaktadır. Verimlilik yaklaşımında kadınların toplumsal katılımlarının sınıllanmasının nedenleri arasında eğitim eksikliği ve verimliliği az olan teknolojiler bulunmaktadır (Moser, 1993: 161170). Kadınların girişimci olarak istihdama katılmasını engelleyen geleneksel toplumsal cinsiyet rollerinin, onların ekonomik ve sosyal açıdan güçlenmesini de zorlaştırması, kadın girişimciliğiyle güçlendirme arasındaki ilişkiselliği göstermektedir. $\mathrm{Bu}$ nedenle kadınların ataerkil kapitalizmin farklı baskı pratiklerinin karşısında güçlendirilmelerini hedefleyen güçlendirme yaklaşımı (1993: 161-170) bu çalışmanın konusu açısından merkezi bir işleve sahiptir.

Güçlendirme yaklaşımını ele almadan önce, kadınların söz konusu bask1 pratiklerine yönelik mücadele biçimlerine kısaca değinmek yerinde olacaktır. Bu kapsamda Kandiyoti'nin (1988: 274-275) “ataerkil pazarllk" olarak kavramsallaştırdığ1 ve "kadınların somut baskı kalıpları içinde izledikleri stratejilerin”, sınıf ve etnisite gibi değişkenlere göre farklılaşmasına değinilebilir. 
Kandiyoti (1988: 275) ataerkil pazarlığa dair bölgesel düzeyde yaptı̆̆1 sinıflandirmada Sahra altı Afrika, Orta Doğu, Güney Asya ve Doğu Asya’yı kategorik olarak değerlendirmektedir. Bu gruplandırmaya göre dünyanın en yoksul bölgelerinden birisi olan ve özellikle kırsal alanda kadın emeğinin görünmez kılındığ1 Sahra altı Afrika'da (Whitehead ve Bloom, 1992: 42) kadınlar ataerkil sistemde sahip oldukları göreli özerklik alanlarını korumaya yönelik stratejiler izleyerek çokeşliliğin neden olduğu güvencesizliği telafi etmeye çalışmaktadırlar (Kandiyoti, 1988: 277). Bu stratejiler, küresel işbölümünün gelişmesiyle birlikte piyasa ekonomisi ve ataerkil dizgenin birleşmesinin sonucu olan eşitsizliklerin ürettiği sorunların artması çerçevesinde de düşünülebilir. ${ }^{10}$

Kandiyoti'nin (1988: 278) sinıflandırmasının ikinci grubunda yer alan ülkeler "klasik patriyarka" başlığı alıında ele alınırken bu toplumlarda kadınlar evlilik yoluyla gittikleri evlerde eşlerinin ailesine itaat ederek emeklerini değersizleştiren süreçleri yeniden üretmektedirler. Kadınlar bu süreçte izledikleri stratejiler çerçevesinde eşleri ve oğulları üzerinde uyguladıkları manipülasyon aracıllğıyla kendi güvenliklerini artırmaktadırlar (1998: 280). Kadınların kendi yaşam şanslarını maksimize etmelerine imkân tanımasına rağmen bu tarz taktikler ataerkil sistemin dinamiklerini dönüştürme kapasitesinden büyük ölçüde yoksundur (Kandiyoti, 1998: 280). Tam da bu bağlamda kadınların güçlendirilmelerine yönelik politika ve yaklaşımların dönüştürücü potansiyeli ortaya çıkmaktadır. Mevcut kalkınma yaklaşımları arasında güçlendirme yaklaşımının da diğer yaklaşımlara nazaran daha eşitlikçi bir içeriğe sahip olduğu düşünülebilir. 1990'lı yılların başat kalkınma yaklaşımı olan güçlendirme (empowerment), kadınlara verili toplumsal cinsiyet rollerinden sıyrilmalarını sağlayacak olanaklar sunulması, kadınların sosyal ve ekonomik yaşama katılarak kaynaklara erişimlerinin teşvik edilmesi anlamına gelir. Kadınların toplumsal statülerini yükseltmeyi hedefleyen güçlendirme yaklaşımı öncelikle kadınların stratejik toplumsal cinsiyet gereksinimlerine ulaşabilmelerini sağlamak için pratik toplumsal cinsiyet gereksinimlerini elde etmelerini savunmaktadır (Moser, 1993: 166-167). Böylelikle kadın girişimciliğinin teşvik edilmesinin, girişimcilik kültürü ve davranışlarını pekiştireceği düşünülmektedir.

Kadınların güçsüzlügü temel olarak ekonomik faktörlerden kaynaklandığı için eğitim vasıtasıyla yaratılacak bir farkındalı̆ı̆n, kadınların güçlenmelerinde yeterli olmayabileceği, kadınların farklı bağlamlarda da güçlenmelerinin koşulunun ekonomik unsurlara dayandığı yönünde bir iddianın varlığına rağmen (Fernando, 1997: 157) güçlendirmenin çok boyutlu bir strateji olduğu göz önünde bulundurulmalıdır. Öyleyse ekonomik, toplumsal ve kültürel olarak güçlendirme perspektifi, toplumsal kalkınmayla yoksulluk arasındaki karşıtlıkların çözülebilmesi hususunda öncelikle kendine güven ve özyeterliliği geliştirerek kadınları

10 Bu kapsamda özellikle Fas-Bangladeş arasındaki ataerkil kuşakta yer alan ülkelerde sermayenin kırsal alana yayılması cinsiyet ayrımcılığını daha fazla körüklemektedir (Whitehead ve Bloom, 1992: 42). 
güçlendirmeyi içermektedir (Toksöz vd., 2001: 33). Bu noktada kadınların güçlenmelerinin sağlanabilmesi için yedi temel özelliğin gerekliliğine değinilmektedir: Karar alma mekanizmalarına katılmak, hane içi kaynaklar üzerinde denetim sağlayabilmek, girişimcilik vasıflarını kazanmak, eş ve toplum tarafindan saygı görmek, hane içi yükümlülüklerde eşten yardım görmek, harcamalar üzerinde karar verebilme yetisine ve kendi vaktini kullanabilme özgürlüğune sahip olmak (Makombe, 2006: 57). Kadınların güçlendirilmesi ve yoksulluk döngüsünden kurtulabilmeleri için hane içindeki kaynaklar üzerinde eşleriyle eşit düzeyde karar alabilme imkânının bulunması kritik önemdedir. Ancak yoksulluğun kadınlaşmasının geniş kabul gören bir kavram olmasına rağmen hane içinde kadınlar aleyhine işleyen, cinsiyetler arasındaki eşitsiz kaynak bölüşümüne odaklanılmamaktadır. ${ }^{11}$ Böylelikle evli kadınların deneyimledikleri hane eksenli yoksulluk biçimleri de bilimsel çalışmalarda görünmez hale gelir (Ekiz Gökmen ve Gökovalı, 2016: 157-158). Mardin ve Muğla'da yapılan, hane içindeki kaynakların eşitsiz bölüşümünün kadınları ne denli yoksullaştırdığına dair bulgular içeren bir araştırmaya göre kadınlar hem yoksul hem de yoksul olmayan hanelerde erkeklere oranla kaynaklara daha sinirlı biçimde erişmekte, kararlara katıllım açısından ikinci planda kalmakta ve aile içi şiddete uğramaktadırlar. Araştırmada TÜIK'in yoksulluk sınırının ve salt gelir düzeyi yetersizliğine odaklanan yaklaşımların kadınların yoksulluğunu derinlemesine analiz etmede son derece yetersiz olduğu da bulgulanmıştır (2016: 181). Thinker'ın (1990: 43) kadınların toplumsal projelere katılmalarının, kendilerini ifade edebilmelerinin, sosyal ve özel sorunlarının paylaşımında yalnız olmadıklarının bilincine sahip olmalarının sağlanarak, yalıtılmışlık ve marjinallikten kurtulabilmelerine dair önerileri de bu saptamayla uyumludur.

\section{Patriyarkal Toplumsal Cinsiyet Rolleri Ekseninde Kadın Girişimciliği}

Güçlendirme yaklaşımı kapsamında kadın girişimciliği, kadınların patriyarkal engelleri aşmak suretiyle bağımsız özneler olarak ekonomik yaşama katılmalarını sağlayabilme potansiyeline sahip olması nedeniyle dünyada ve Türkiye'de artan oranda ilgi odağı hâline gelmektedir. Bu açıdan girişimcilik kavramı, bireylerin ya da sosyal grupların herhangi bir işletme girişimi kurmasını ifade eder. İlgili literatürde girişimcilik olgusunun kalkınma süreçleri bağlamında önemli bir işleve sahip olduğu görülmektedir. Girişimcilik bir yandan da "sermayeyi mobilize etmek, doğal kaynakları keşfetmek, piyasalar yaratmak ve ticareti sürdürmek” (Gurnani, 2016: 1)

11 Kadınların hane içinde yaşadıkları yoksulluğu tespit edebilmek için hane davranışlarını inceleyen üniter ve kolektif olmak üzere iki temel model bulunmaktadır. Bu ayrıma göre üniter modelde hanehalkının bütçe kısıtı altında ortak iktisadi amaçlar için aynı düşünceleri benimseyerek hareket ettikleri, kolektif modelde ise bireylerin kaynak bölüşümüyle ilgili farklı pazarlık güçlerine sahip oldukları varsayılmaktadır (Ekiz Gökmen ve Gökovalı, 2016: 158). 
anlamına gelmektedir. Özellikle yar1-çevre ve çevre ülkelerde ekonomik büyümenin sağlanması için izlenecek politikalarda başat ekonomik aktörlerden biri olarak girişimcilik pratikleri kullanılmaktadır.

Ortaya çıkışı küresel kapitalizm çağına rastlayan girişimcilik uygulamalarının toplumsal cinsiyetle olan ilişkiselliğini kurabilmek için öncelikle kadınların toplumsal rolleri ele alınmalıdır. Moser'e (1993: 1-2) göre kadınlara toplumsal olarak yüklenen çoklu rolleri, kamusal alandaki otorite, özerklik, zorunluluk, iş yükü ve sorumluluklar belirlemektedir. Peki, girişimcilik olgusu kadınların toplumsal rolleriyle nasıl bağdaşacaktır? Bu sorunun cevaplanması için kadınların patriyarkal toplumsal alanda deneyimledikleri eşitsizliklerin çözümlenmesi gerekmektedir. Kadınlar hane içi roller, toplumsal cinsiyete dayalı önyargilar, eğitim düzeylerinin düşüklüğü ve firsat eşitsizliği gibi nedenlerle ekonomik ve sosyal yaşama sınırlı bir şekilde katılmaktadır. Ekonomik faaliyetlerde bulunsalar ve çalışma yaşamına katılsalar bile, maddi birikim sağlamaları ve kazandıkları gelirin kendileri tarafindan kullanılması önündeki yapısal-toplumsal engeller nedeniyle kaynaklara erişimde ciddi problemlerle karşılaşmaktadırlar. Bir yandan da ataerkil değerler sistemi kapsamında kadınların girişimcilik pratiklerindeki rollerine dair tortulaşmış kalıp yargılar bulunmaktadır. Kadınların değişime kapalı olarak görülmeleri, liderlik yeteneklerinin erkeklere göre kısıtlı olduğunun düşünülmesi, erkekler kadar inisiyatif alamamaları, almaları durumunda ise erillikle damgalanmaları, pek çok profesyonel çalışma alanının erkeklerce domine edilmesi nedeniyle bu alanlarda etkili projeler geliştirememelerine dair düşünceler bu kalıp yargılar arasında sayılabilir (Aalito, 2008: 30). Üstelik özellikle genç kadın girişimciler "devlet kurumları, müşteriler, tedarikçiler tarafindan yapılan ayrımcılık", "iş bağlantıları ya da meslektaşları tarafindan önemsenmemek", "cezbedici fonlar bulabilmek konusundaki güçlükler", "aileden ve arkadaşlardan alınabilecek olan desteklerden mahrumiyet", "devlet kurumları, bankalar ve iş destek organizasyonlarından iyi tavsiyeler alamamak" gibi yoksunluklar ve dezavantajlara maruz kalmaktadır (Still, 2005: 62).

Toplumsal cinsiyet rollerine dayanan patriyarkal kalıp yargilar, kadınların girişimci olmalarını zorlaştırmakta ya da engellemektedir. Girişimciliğe dair, erkeklikle özdeşleştirilen kolektif algilar ve toplumsal kodlar, rekabetçilik, özgüven, yaratıcllk, risk alabilme yeteneği gibi özelliklerdir. Bu alg1 ve kodlar, yapılan girişimcilik araştırmalarına çoğu zaman yansımış, girişimcilik kavramı tanımlanırken bile kadın ve erkeğin aynı olduğu varsayılarak cinsiyet duyarlılığına sahip olmayan öznel ve özcü yaklaşımlar geliştirilmiştir (De Bruin vd., 2006: 586). Sözgelimi Bruni ve arkadaşları (2005: 1) erkekliğe atfedilen kişilik özelliklerini, mitolojik bir karakter olan Merkür'le özdeşleştirmektedirler. Merkür karakterinin kişilik özellikleri olan faydacılık, kurnazlık, risk alabilme, aktiflik gibi özellikler eril; pasiflik, uyum sağlama ve esneklik ise kadınlara ait olan dişil özelliklerdir. Girişimcilik "erkekliğe dair değerler evreninde" yer alır, "hegemonik bir erkeklik biçimini simgeler ve dişil değerlere zit bir şekilde" var olur. 
Kadın girişimciliğiyle ilgili yapılan çalışmalarda kalkınmada girişimciliğin rolü, kadın girişimciliğinin önündeki engeller ve bu engelleri aşmaya yönelik düzenleme gereksinimleri, kadın yoksulluğunun önlenmesinde girişimciliği teşvik etmenin avantajları gibi temalar üzerinde durulmaktadır (Ahl, 2006; De Vita vd., 2014; Manolova vd., 2008; Okpara vd., 2011). De Vita ve arkadaşlar1 (2014: 453), farklı ülkelerde kadın girişimciliğini analiz eden 70 farklı makaleyi değerlendirdikleri araştırmalarında, 2007 ylından itibaren gelişmekte olan ülkelerdeki kadın girişimciliğine yönelik çalışmaların sayısıyla kadın girişimciliği pratikleri arasında doğru yönlü bir ilişki bulunduğunu ileri sürmüşlerdir. Yazarlara göre bu alana yönelik ilginin artması, gelişmekte olan ülkelerdeki kadın girişimci sayısındaki artışla ilişkiseldir. Söz konusu ülkelerdeki evli ve çocuklu kadınlar kayıtlı istihdama erişmede zorluklar yaşarken, girişimcilik ekonomik ve toplumsal sorunlara karşı anahtar bir role sahip olmuştur. Bu noktada girişimciliğin ekonomik fonksiyonu olarak, ülkelerin büyüme ve işsizliği azaltma stratejisine sağlayacağ1 katkı öne sürülmektedir. Diğer taraftan biyolojik cinsiyetin toplumsal alana yansımasiyla ortaya çıkan toplumsal cinsiyet eşitsizliğinin giderilmesinin de kadınların mesleki bir kimlik edinebilmeleriyle iliş̧kili olan girişimciliğin sosyal fonksiyonu olduğu savunulmaktadır (2014: 457-458).

Belirgin bir biçimde girişimciliği teşvik eden uygulamaların, gelişmekte olan ülkelerdeki kadın işsizliği ve yoksulluğunun önlenmesinde en etkili araç olduğu öne sürülmektedir (De Vita vd., 2014: 457). Kadınların işgücü piyasalarında ücretli istihdama katılmak yerine girişimcilik pratiklerini deneyimlemeleri gerek ekonomik gerekse toplumsal cinsiyet açısından daha ulaşılabilir bir hedef olarak değerlendirilmektedir (Okpara, 2011: 232). Öte yandan girişimciliğin tarihsel olarak eril bir yapıya sahip olması da (Ahl, 2006: 3) toplam istihdam içerisinde bir erkek egemenlik alanı oluşturmaktadır (Manolova vd., 2008: 78). Bu noktada girişimciliğin eril bir yapısı bulunsa da, teknolojik ve toplumsal gelişmelerin ve istihdam ilişkilerinin yapısında yaşanan dönüşümlerin kadın girişimcilerin sayısını artırdığını belirtmek gerekmektedir. Özellikle de girişimcilik pratiklerine yönelmenin bireysel motivasyon kaynakları önem kazanmaktadır. Manolova ve arkadaşlarının (2008: 78) yaptığı araştırmanın bulgularına göre, erkeklerin ve kadınların girişimciliğe yönelmedeki motivasyon kaynakları farklılaşmaktadır. Erkekler için girişimcilik kendini gerçekleştirme ve finansal başarı açısından motive edici olurken, kadınlara bunların yanı sıra statü ve özerklik aracı olarak da motivasyon sağlamaktadır. Ancak yine de bireysel faktörlerin toplumsal/sınıfsal yap1 ve dinamiklerden bağımsız olarak ele alınması, toplumsal cinsiyet rolleri bağlamında yapılan bir analiz açısından rasyonel gözükmemektedir. Zira kadınların sahip olduğu veya elde ettiği bireysel motivasyon kaynakları, onların pratikte girişimci davranışı göstermelerini tek başına sağlayamamaktadır.

Kadın girişimciliğinin geliştirilmesinin önünde toplumsal cinsiyet rolleriyle ilişkisel olarak ekonomik, kültürel, sosyal ve bireysel fazlaca etken bulunmaktadır. Kadınların sahip olduğu toplumsal cinsiyet rolleri gereği eğitim olanaklarına 
erkeklerle eşit bir biçimde erişememeleri, mesleki beceriler geliştirmeye yönelik programlardan mahrum kalmalar1, dinsel-kültürel veya toplumsal normlar bağlamında istihdam ilişkilerinde ikinci planda yer almaları temel problematiktir. Var olan patriyarkal toplumsal yap1, kadınların girişimciliğe yönelmesinde “toplumsal meşruiyet” sorununu gündeme getirmektedir (De Vita vd., 2014: 457).

Ekonomik ve sosyal risklere karşı girişimcilik pratiklerini deneyimleyen kadınlar serbest piyasa işleyişinde farklı zorluklarla karşılaşmaktadır. Genellikle küçük ve orta boy işletmeler kurabilen kadınlar, piyasada rekabet içinde oldukları erkek girişimciler karşısında finansal destek açısından dezavantajlarla yüzleşebilmektedir. Örneğin Okpara ve arkadaşlarının (2011: 225) yaptı̆̆1 araştırma, Nijerya'daki girişimcilerin yüzde 25'inin kadınlardan oluşmasına rağmen kadınların çok düşük bir oranının banka kredilerine erişebildiklerini bulgulamıştır. Kadın girişimciler işletme geliştirme konusunda erkeklere oranla daha zor şartlarla karşı karşıya kalmakta, maddi duran varlıklara sahip olmamaları nedeniyle de kredi alırken bankalara teminat gösterememektedir. Demek ki işgücü piyasalarında istihdama katılamama sorunuyla karşı karşıya kalan kadınlar girişimci olmaları durumunda da eşitsiz ilişkiler içinde yer almaya devam etmektedir (Ahl, 2014: 14).

Kadın girişimcilerin, karşılaştıkları yapısal ve pratik sorunlara karşı kredi imkânlarının geliştirilmesi önerisinde bulunulmaktadır (Okpara, 2011: 232). Bu noktada kadın girişimciliğinin finansmanında verilen teşviklerin göreli bir sermaye birikimi sağladığını belirtmek olanaklıdır. Fakat genel itibariyle ilgili literatürde teşvik ile sermaye birikimi arasında kurulan ilişkinin sınırlarının yeterince çizilmediği görülmektedir. Bir yandan da ekonomi piyasalarında serbestleşme ve metalaşmanın hâkim olduğu küreselleşme koşullarında, kadın girişimciliği pratiklerinin geniş kapsaml bir biçimde bireyleri yoksulluğun yeni türlerinden kurtarıc1 bir etkisinin bulunmadığı; bireysel düzeyde sağlanan kimi başarı öykülerinin popülerliğinin toplumsal düzeyde bir yoksullukla mücadele stratejisi olamadığ1 görülmektedir. Bilindiği gibi azgelişmiş ve gelişmekte olan ülkelerde yoksulluk, yapısal ve dramatik bir sorundur. Yoksulluğun yapısallaşmasının arkasında yatan temel dinamik ise sermayenin küresel düzeyde serbestleşmesidir (Petras ve Veltmeyer, 2006). Özellikle de uluslararası serbest piyasa ilişkilerinin temel aktörleri olan Dünya Bankası ve IMF'in politikaları, çevre ve yarı-çevre ülkelere önerilen yapısal uyum programlarıyla yoksulluğun derinleşmesi sonucunu doğurmaktadır (Chossudovsky, 1999: 89-94).

\section{Emeğin Feminizasyonu ve Kadın Girişimciliği İlişkiselliği}

Küreselleşme sürecinin ürettiği uluslararası işbölümü çerçevesinde oluşan yeni çalışma biçimlerinin temel görünümlerinden biri olan emeğin feminizasyonu, cinsiyete dayalı işbölümünün yeni kapitalist bağlamının sonuçlarından biridir. $\mathrm{Bu}$ sosyal gerçekliğin anlaşılmasında üretim ilişkilerine odaklanmak analitik bir çerçeve 
sağlar. Öncelikle yeni kapitalizmde kadınların sermayenin ucuz emek ihtiyacını karşılamada işlevsel kilındığı belirtilmelidir. Kadınların ucuz emek rezervi olarak kullanılmasıyla, küresel kapitalizmin emek maliyetlerinin düşürülmesi ve kâr maksimizasyonunun sağlanması mümkün olmaktadır (Mackintosh, 1981: 7). Öte yandan Maria Rosa Dalla Costa tarafindan geliştirilen "sosyal fabrika" kavramının 1şığında, kadınlar hem üretim ilişkilerinde yer alarak hem de karşıllğı ödenmeyen ev içi emek sarf ederek sermayenin gereksindiği işgücünün yeniden üretimini sağlamaktadır. Dolayısıyla kadınların hane içinde emek sarf etmeleri meta üretiminin bir türevi olup üretim ilişkileriyle bütünleşmiştir. Mackintosh (1981: 11-12) üretim eylemini ortaya çıkartan yeniden üretim olgusuna ve yeniden üretimin emeğin cinsiyetçi işbölümüyle birleşmesine vurgu yapmaktadır. Yeniden üretimin "insanın yeniden üretimi”, "emeğin yeniden üretimi” ve "toplumsal yeniden üretim” olarak üç bileşenli bir yapısı bulunmaktadır. Bu süreçte kadınlar hem toplumsal cinsiyete dayalı ayrımcilığa ${ }^{12}$ hem de issgücü piyasalarında emek denetiminin cinsiyetçi pratiklerine maruz kalırlar. Kadınlar üzerinde daha belirgin olan emek denetimi pratikleri, ayrımcılık süreçlerini katmanlı hale getirmektedir. Bu bağlamda Munck (1995: 108) özellikle Üçüncü Dünya ülkelerinde faaliyet gösteren fabrikalarda sermayenin emek üzerindeki denetiminin cinsiyetçilikle yoğun biçimde birleștiğini vurgulamaktadır. Kırsal alanda da ataerkil kültürün belirlediği cinsiyete dayalı işbölümüyle tarımın ticarileşmesi arasındaki kesişimsel sosyolojik ilişkiler bağlamında düşünülmesi gereken kadın emeği sömürüsü aile içi geçimlik üretim yapılan tarım topraklarının metalaşması sürecinde yoğunlaşmıştır. Bilindiği gibi ücretsiz çalışma türlerinin büyük bir oranını oluşturan tarımda ücretsiz aile işçiliğinin, ulusal üretimin ve gelir hesaplamalarının dışında bırakılmış olması (Beneria, 2003: 134), kadın emeğinin görünmezliği ve sömürüsüyle ilișkilidir. Üstelik kırsal alana ve kadınların çalışma ilişkilerine dair literatürde küçük çiftçi ve kırsal yoksullar gibi tanımlamalar çoklukla erkek odaklı olarak ele alınmaktadır. Oysa gerçekte bu kesimlerin büyük çoğunluğu kadınlardan oluşmaktadır ${ }^{13}$ (Ostergaard, 1992: 2).

12 Ataerkil kapitalist sosyo-ekonomik formasyonun işgücü piyasalarında sadece kadınlar ve erkekler arasında değil, kadınların kendi aralarında da ayrımcılı̆̆a dair kategoriler oluşmaktadır. Bu kapsamda genç kadınlar yaşlarıyla bağlantılı ayrımcılık pratiklerine daha fazla maruz kalmaktadır (Still, 2005: 62).

13 Sözü edilen cinsiyete dayalı eşitsizlikler kırsal alanda cinsiyete dayalı yatay ayrışma üzerinden de görülebilir. Sözgelimi hayvancılıkla ilgili faaliyetlerde, süt sağmak ve hamile hayvanların bakımı; kümes hayvancılığı ve ipekçilik, mahsulün toplanmasındaki ara aşamalar, meyve, sebze üretimi kadınların görevi olarak belirlenmiştir. Erkekler tarafından yürütülen önemli bir faaliyet alanı ise üretilen ürünlerin pazarlanmasıdır (Akder, 2003: 121 124). Kadınlar üretim etkinlikleriyle ilgilenirken, erkeklerin ürünlerin pazarlanması fonksiyonunu yürütmeleri, Foucaultcu anlamda güç ve iktidar ilişkileri açısından hiyerarşik olarak erkeklerin kadınlardan daha üst bir statüye taşındığı bir yönetsellik de içermektedir. Nitekim kadınlar hane içi yükümlülüklerinin yanı sıra yoğun biçimde tarımsal üretime katılmaktadır (Yıldırak vd., 2003: 2). 
Emeğin küresel feminizasyonuna ve hem kentsel hem de kırsal alanda kadın emeği sömürüsünün yoğunlaşmasına koşut olarak yoksulluk da kadınlaşmıştır. Pearce (1978: 28-36) küreselleşmenin ve postfordist üretim biçiminin başlangıç zamanlarına tekabül eden 1978 yılındaki çalışmasında, literatürde ilk kez "yoksulluğun kadınlaşması" kavramını, dünyadaki yoksulların fazlasıyla yüksek bir oranının kadınlardan oluştuğunu belirterek kullanmıştır. Pearce'ın (1978: 28) araştırmasındaki bulgulara göre, sayısal olarak 15 milyon yoksul bireyin oluşturduğu nüfusun 16 yaşın üstünde olan üçte ikisi, dramatik bir biçimde kadınlardan oluşmaktadır. Özellikle ABD'nin çok sayıda düşük ücretli ve sosyal güvencesiz iş üreterek işsizliği azaltma politikası çerçevesinde, kadınların istihdam piyasalarında işgücüne katılım oranları artmıştır. Fakat bir yandan da mevcut yoksulluğun yüksek oranlarının yine kadınlardan oluşması, Pearce'ın yoksulluğun kadınlaşması kavramının analitik bir kullanışlılığa sahip olduğunu göstermektedir.

Özellikle küreselleşme sürecinin ürettiği esnek birikim ve uzmanlaşmaya dair çalışma ilişkilerindeki dönüşümler, "hak temelli yoksullukla mücadele siyasalarından" (Sallan Gül, 2005: 25) vazgeçilmesiyle kadın yoksulluğunun yeni görünümlerini ortaya çıkartmıştır. Örneğin Sallan Gül'ün (2005: 31) Ankara'da yoksulluğun kadınlaşması bağlamında yaptığı araştırmada yoksulluk yardımı alanların mutlak yoksulluk içinde oldukları saptanmıştır. Bir yandan da yoksulluk yardımı alanların çoğunluğu kadınlardan oluşmaktadır (2005: 31-32). Türkiye'de yoksulluğun belirgin biçimde kadınlaştığını analiz eden bir diğer çalışmaya göre (Gökovalı ve Danışman, 2010: 197), yoksulluk neredeyse toplumun tümü için bir sosyal sorun niteliğindedir. $\mathrm{Bu}$ açıdan toplumun yoksulluğuna dair tümel çalışmaların yanı sıra kadınların yoksulluğu bağlamında spesifik çalışmalar yürütülmesi gerekmektedir. Makro-ekonomik düzeyde de istikrarlı ve büyüyen bir ekonominin varllğı, yoksullukla mücadelede gerekli enstrümanların, özellikle iş olanaklarının yaratılması ve sağlık, eğitim haklarına erişebilmek açısından zorunludur. Türkiye'de yoksulluğun kadınlaşmasının bir diğer başat nedeni, kadınların emek gücü içinde erkeklere oranla daha düşük bir oranda bulunmalarıdır (Gökovalı ve Danışman, 2010: 198).

Yoksulluk içinde yaşayan kadınların sayısının özellikle azgelişmiş ve gelişmekte olan ülkelerde erkeklere kıyasla önemli oranda artması, kalkınma süreçlerinde kadının konumuna dair tartısmaları daha da önemli kılmaktadır. Bu kapsamda yoksulluğun kadınlaşmasına dair dörtlü bir sınıflandırma, yoksulluğun katmanlarını görmek açısından anlamlıdır: "Yoksullar arasında kadınların oranının fazlalığı", "kadın yoksulluğunun tesadüfi olmayan cinsiyet fark1 gözeten etkileri”, "kadın yoksulluğunun düşük görünürlük düzeyi”, "yoksullar arasında kadının temsilinin aşırı bir biçimde giderek daha fazla artması" (Coughelin ve Thomas, 2002: 24). Amartya Sen (2003) tarafından geliştirilmiş olan ve kadınların yaşam standartlarının yükseltilmesini vurgulayan yapabilirlik yaklaşımı (capability approach) ise, kadın yoksulluğunun anlaşılması açısından önemlidir. Böylelikle yoksulluğun çözümlenmesinde elverişli bir normatif çerçeve oluşturulacağını ileri 
süren Nusbaum (1999: 229) özellikle paternalizm ve kapitalizm koşullarında kadınların yapma hakkına sahip olmaları gerektiğini savunmaktadır.

Kadın yoksulluğu tartışmalarında kadın girişimciliği bir yoksullukla mücadele stratejisi olarak değerlendirilmiştir. Gerçekten de 1980’li yıllardan itibaren kadın girişimciliği, kadın yoksulluğu ve işsizliğiyle temel bir mücadele aracı niteliğinde Dünya Bankası ve Uluslararası Para Fonu gibi kuruluşlar ve Avrupa Birliği tarafından teşvik edilmeye başlamıştır. Bu gelişmelerle birlikte kadın girişimciliğiyle ilgilenen araştırmaların sayısında da bir artış gözlenmiştir. Liberal, marksist ve radikal feminist yönelimli çalışmalar, ana akım girişimcilik araştırmalarındaki cinsiyet körü bakış açılarına ve girişimciliğin eril yapısına dikkat çekerek eleştirel yaklaşımlar önermişlerdir. Mevcut eleştirilerin bir bölümü kadın girişimciliğinin sosyal güvenceden yoksun yapısına odaklanmaktadır (Sallan Gül ve Altındal, 2016: 1367). Öte yandan kadınların girişimci olmalarının işgücü piyasasındaki ayrımcılık pratikleri yüzünden güçleşmesi ve girişimcilik faaliyetlerinin yalnız kadınlara özgülenen alanları kapsaması diğer eleştiriler arasında yer almaktadır (2016: 1370). Feminist yaklaşımların bir bölümünün ise kadınlar arasındaki sınıfsal farkları gözetmedikleri iddia edilmiştir. Örneğin kadınların özgürleşmesinin anahtarını, onların otorite sahibi olmasıyla özdeşleştiren liberal feminist yaklaşıma göre, kadınların işveren olması veya üst düzey yönetici pozisyonuna erişmeleri işlevsel bir role sahiptir. Ancak nicel veriler, kadınların karşılaştı̆̆ cam tavanları yıkmasının sosyo-ekonomik kısıtlamalar nedeniyle mümkün olmadığını açı bir biçimde göstermektedir. Bu bağlamda Arruzza ve arkadaşları (2019: 259), işveren veya üst düzey yönetici pozisyonunda yer alan az sayıda kadının cam tavanı kırabildiğini fakat "ezici bir çoğunluğun hâlâ kırık cam parçalarını temizlemeye mahkûm edildiğini”" vurgulamaktadır.

Genel itibariyle yapısal sorunlara palyatif çözümler öneren kadın girişimciliği çalışmalarındaki bir diğer eksiklik sınıfsal analiz ${ }^{14}$ noktasında karşımıza çıkmaktadır. Girişimcilik uygulamaları kısmi maddi destekler aracılı̆̆ıla bireysel düzeyde kadınları özgürleştirici ve güçlendirici süreçleri kimi zaman yaratabilse de toplumsal düzeyde tüm kadınları özgürleştirecek bir bütünsellikten uzaktır. Üstelik maddi destekler, kadınların girişimci olarak işgücü piyasasına dâhil olmasını sağlasa da yeni yoksulluğa dair çözümler üretememektedir. Öte yandan kadınlar eğitim düzeylerinin düşüklüğ̈̈, verili sosyo-kültürel önyargılar, maruz kaldıkları ayrımcılık ve teknolojiye, bilgi kaynaklarına ve sermayeye ulaşmadaki engellerden dolayı imalat sanayisi gibi sektörlerden ziyade emek yoğun sektörlerde girişimcilik faaliyetlerinde bulunmaktadır. Bunun yanı sıra kadınların yürüttükleri etkinlikler genellikle düşük sermayeye dayanan, küçük ölçekli ve daha az kâr sağlayan işlerdir (Bruni vd., 2003:

${ }^{14}$ Ellen Meiksins Wood (2018) kapitalizmin yarattı̆̆ı sömürü ilişkilerini görünmez kılan uygulamaların sınıf kapasitesinin kullanılmasının önünde engel teşkil ettiğini belirtmektedir. Bu çalışma kapsamında ele alınan girişimci teşviklerinin kadınlar açısından göreli katkıları bulunsa da, teşviklerin temelinde bu tür bir amacın varllğını sürdürdüğünü belirtmekte yarar bulunmaktadır. 
15). Toplum içindeki tarihsel konumlarıly bağlantılı olarak geleneksel ürünlerin üretilmesi, pazarlanması, satış1 ve hizmetler sektörü kapsamında yapılan işler, kadınların girişimcilik faaliyetlerinde bulunmak üzere teşvik edildikleri alanlar olmuştur (Yetim, 2002: 80).

Kadın girişimcilerin daha çok emek yoğun sektörlerde faaliyet göstermeleri, onları sınıfsal olarak küçük ölçekli işletmecilikle ücretli emek arasında bir kategoride tutmaktadır. $\mathrm{Bu}$ belirsiz konumdaki kadınlar, yoksullaşma, mülksüzleşme ve marjinalleşme çerçevesinde, ataerkil kapitalizme içkin olan piyasa risklerinden ötürü Weberyen (2017) sınıf analizi kapsamında olumsuz ayrıcalıkl, orta sınıf ya da olumlu ayrıcalıklı sinıf gibi farklı kategoriler arasında salınmaktadır. Girişimcilik teşviklerinin yarattığı sınıfsal belirsizlik bir sınıfsal deformasyon olarak düşünülebilir. Özellikle küresel dünyanın güvencesizlikleri bu deformasyonu besleyebilmektedir. Öte yandan iflas eden girişimciler olduğu kadar sermayesini büyüterek girişimcilik faaliyetini devam ettirenler de bulunmakta, pek çok küçük ölçekli firma ekonomi piyasalarına katılarak istihdam yaratmaktadır. Burada önemli olan husus sözü edilen firmaların idarecileri içinde kadın girişimcilerin yer almasıdır (Coughelin ve Thomas, 2002: 5).

Kadın girişimciliği uygulamaları dünyadaki ülkelerin refah rejimlerine göre farklılık göstermektedir. Örneğin sosyal demokrat refah rejimlerinden biri olan İsveç'te işini yeni kuran kadın girişimciler, başarısız olmaları durumunda devlet yardımlarının sağlayacağı çocuk bakımı ve sağlık hizmetlerinden yararlanabilmenin potansiyel güvencesiyle de işletmelerini kurmaktadır. Oysa ABD'deki kadın girişimciliği, İsveç'ten son derece farklı bir sosyo-ekonomik içeriğe sahiptir. ABD'de çocuk bakımına ve sağlık hizmetlerine dair herhangi bir devlet katkısı ve güvencesi olmadığından, iş kuran kadın girişimciler başarısız oldukları takdirde herhangi bir devlet yardımından faydalanamayacaklarını bildikleri için kimi bireysel önlemler almak suretiyle girişimci olmaktadırlar (Fairclough, 2012: 103). Hindistan ve Bangladeş gibi azgelişmiş ülkeler söz konusu olduğunda ise uluslararası kuruluşların yönlendirdiği politikaların izlenmesine destek veren projeler gündeme gelmiştir. Örneğin Shukla'ya (2007: 1) göre Hindistan'da küçük işletmeler ve girişimcilik, ülke kalkınmasında önde gelen sektörlerde, istihdam alanlarındaki üretkenlikte ve gelirin toplumda daha eşit dağılımının temininde önem kazanmaktadır. Çeşitli proje ve uygulamalar, kadınlara mikro kredi verme, girişimciliğe dair çeşitli eğitim programlarına katılım imkânı sunma, mesleki eğitim olanaklarından yararlandırma gibi bileşenleri içermektedir. Bilindiği gibi mikro kredi uygulamaları Dünya Bankası tarafından Bangladeş ve Hindistan'da denenmiştir. ${ }^{15}$ Kimi araştırmalarda ise demokrasi kültürünün gelişmesini sağlayacak biçimde mikro girişimcilik ve kadının güçlendirilmesi arasında ciddi bir korelasyon bulunduğu vurgulanmaktadır (Jerinabi, 2007: 51). 1975 yilında Mexico City'de düzenlenen BM 1. Dünya Kadın Konferansı'nda tasarlanan ve kadınların finansal

15 Ayrıntılı bilgi için bkz: (Yunus, 1999). 
kaynaklara erişimlerini kolaylaştırarak onların ekonomik yaşama katılımlarını artırmayı hedefleyen Dünya Kadınlar Bankacilığ (WWB-Women's World Banking) (Women's World Banking, 1996) ise mikro kredi faaliyetlerinin yürütülmesinin kurumsallaşması açısından önemli bir örnektir.

Avrupa Birliği nezdinde ise girişimciliğin desteklenmesi amacıyla geliştirilen COSME $^{16}$ programı kadın girişimciliğine dair program ve projeler bağlamında ele alınması gereken bir örnektir. Temel olarak, küçük ve orta boy işletmelerin rekabet edebilirliğini artırmayı amaçlayan bu program kapsamında girişimcilerin desteklenmesi, AB'nin ekonomik büyümesiyle ilişkilendirilmektedir. Kadın girişimciler için oluşturulan WEgate platformu ${ }^{17}$ ile kadınlara eğitim, mentörlük, tavsiye ve ağ oluşturma destekleri sağlanırken; WES ağ1 ${ }^{18}$ araciliğtyla $A B$ ülkeleri, İzlanda, Norveç ve Türkiye'de kadın girişimcilerin desteklenmesi hedeflenmektedir. ${ }^{19}$

ILO (2019: 89-90) da AB gibi kadın yoksulluğunun önlenmesi, toplumsal cinsiyet eşitsizliğinin giderilmesi ve kadınların kayıtlı bir şekilde istihdama katılmaları gibi amaçlarla girişimciliği teşvik eden uygulamaları desteklemekte ve kadın girişimciliğinin önündeki engellerin bertaraf edilmesi amacıyla temel becerilerin geliştirilmesini hedefleyen eğitimler düzenlenmesi, teknolojik ve finansal okuryazarlığın artırılması, kapasite geliştirmeye yönelik projelerin hayata geçirilmesi, toplumsal cinsiyet eşitsizliğine yol açan mevzuatın gözden geçirilmesi gibi önerilerde bulunmaktadır. Birleşmiş Milletler Sürdürülebilir Kalkınma Hedefleri²0 ile uyumlu olan ve insan onuruna yaraşır işlerde toplumsal cinsiyet eşitliğinin sağlanması amacını içeren söz konusu öneriler, özellikle 5 numaralı toplumsal cinsiyet eşitliği ve 8 numaralı insana yakışır iş ve ekonomik büyüme hedefleriyle doğrudan bağlantılı olup diğer hedeflerle dolaylı olarak ilişkilidir.

ILO (2019: 90) kadınların girişimciliğe yönelmesinin önünde önemli bir engel olan finansman sorununa yönelik öneriler de getirerek kadınların girişimci olabilmesi ve işletmelerini geliştirebilmesi için banka kredilerine erişimde kolaylıklar sağlanması gerektiğini vurgulamaktadır. ILO finansman sağlama konusunda olumlu bir örnek olarak Meksika'da kadınların kredi kullanım oranlarının artmasını göstermektedir. Nitekim ülkede 2016'dan 2018'e dek kadınların kredi kullanım

\footnotetext{
16 Europe's Programme for Small and Medium-sized Enterprises.

17 The European Gateway for Women's Entrepreneurship.

18 Women Entrepreneurship.

${ }^{19}$ COSME programı hakkında ayrıntılı bilgi için bkz:
}

https://ec.europa.eu/growth/smes/cosme/supporting-entrepreneurs en (07.06.2021).

${ }^{20}$ Birleşmiş Milletler ekonomik kalkınmanın yanı sıra küresel düzeyde toplumsal kalkınmayı da amaçlamaktadır. Bu çerçevede 2030 yllı için öngördüğü projeksiyona göre 17 temel hedefi bulunmaktadır. $\mathrm{Bu}$ hedeflere ilişkin ayrıntilı bilgi için bkz: https://www.tr.undp.org/content/turkey/tr/home/sustainable-development-goals.html (10.04.2021). 
miktarı 2 katına ulaşmıştır. ${ }^{21}$ Kredi kullanımının artmasına bağlı olarak kadın girişimcilerin sayısında artış yaşanacağı, diğer taraftan hâlihazırda faaliyette bulunan kadın girişimcilerin işletme ölçeklerini geliştirebileceği savunulmaktadır.

Dünya Bankası ve Avrupa Birliği bünyesinde yürütülen kurumsal programlar çerçevesinde, girişimcilik uygulamasının ev işiyle ücretli iş arasındaki ayrımları sarsarak kadınlara yeni alternatifler sunabileceği yönünde bazı tartışmalar mevcuttur. Bu bağlamda önemli bir sorunsal, girişimciliğin gerçekten kadınların hane içinde ve ücretli işte sarf ettikleri emek üzerinden şekillenen çifte yüklerini ortadan kaldırıp kaldıramayacağıdır (Greer ve Grene, 2003: 9). Bu noktada girişimci kadınların ücretli işlerde çalışan kadınlarla ya da girişimci erkeklerle olan farklılıklarını araştırmayı amaçlayan karşılaştırmalı çalışmaların gerekliliğine dikkat çekilmektedir (Butler, 2005: 1). Gerçekten de kadın girişimciliğinin özendirilmesinin arkasında, girişimciliğin kadınlara daha esnek çalışma saatleri sunarak, onların ev işleri/aile yükleri ve iş hayatı üzerinde denge kurabilmelerini sağladığ1 varsayımı yatmaktadır. ${ }^{22}$ Fakat iş ve aile dengesinin hangi gelir seviyesi üzerinden kurulduğu ve kapitalizmle patriyarka ilişkiselliğinde kadınların ne oranda özgürleşebildikleri, kültürel, sınıfsal, ekonomi-politik gerçeklikler açısından ülkeler arasında ciddi düzeylerde farklılaşmaktadır.

\section{Patriyarka ve Yoksulluk Bağlamında Dünyada ve Türkiye'de Kadın Girişimciliği}

Kadın girişimciliği, küreselleşme sürecinin etkisiyle, özellikle 1980'li y1llardan itibaren farklı ülkelerde olduğu gibi, Türkiye'de de artan kadın işsizliği ve yoksulluğuyla mücadele stratejisi olarak uygulanmıştır. Bu kapsamda 1990'lardan itibaren kadın girişimciliğinin desteklenmesi, siyasi iktidarların gündeminde yer almıştır. Girişimcilikte kurumsallaşmanın başladığ $1^{23}$ bu dönemden itibaren kadınların küçük işletmelerinin gelişmesi ve ücretli istihdama ek gelir sağlanması hedeflenmiştir (Sallan Gül ve Altındal, 2016: 1362). ${ }^{24}$

${ }^{21}$ ILO'nun (2019: 90) 2019 yılında yayımladı̆̆1 “A Quantum Leap For Gender Equality: For a Better Future of Work For All” başlıklı rapora göre, Meksika'da kadınların kredi kullanım sayısının 2016 yllından 2018'e ulaşıldığında 7 binden 14 bine çıktığı belirtilmektedir.

22 Kalkınma plancılarının ilk uygulamalarında da kadınlar, çalışan birey değil anne olarak değerlendirilmiştir. Örneğin sağlık programları genellikle çocuklara odaklanmıştır fakat çocukların sağlığının annelerinin sağlığına bağlı olduğu gerçeği göz ardı edilmiştir (Thinker, 1990: 36).

23 Türkiye'de kadın girişimciliğiyle ilgili kurumsal yapıya dair ayrıntılı bilgi için bkz: (Sallan Gül ve Altındal, 2016: 1372).

24 Türkiye'de 2002 yılında kurulan Türkiye Kadın Girişimciler Derneği (KAGIDER), kadınların politik, ekonomik ve sosyal anlamda güçlenmesi ve toplumsal cinsiyet eşitliğinin sağlanması süreçlerine katkıda bulunmayı amaçlamaktadır 
Öte yandan Türkiye'de ücretli çalışanlanı koruyan iş kanunlarının deregülasyonu ve özelleştirme süreçlerinin etkisiyle işgücü piyasalarının giderek istikrarsızlaşması, uzun süreli işsizlik oranlarıyla birleşerek hem işgücü piyasalarına katılamayan hem de çalışan kadınları dramatik biçimde etkilemiştir. Ekonomipolitik etmenlerin yanı sıra patriyarkal dizgenin belirlediği kültürel desenlerin etkisiyle kadınların işgücüne katılım oranları yetersiz düzeydedir. Türkiye'de kadın istihdamının düşüklüğü genel olarak düşük istihdam sorununu oluşturan temel etmendir (Toksöz, 2007: 100). Kadınların erkeklerle aynı vasıfları edinebilme olanaklarından yoksun bırakılmaları, çalışma hayatına katılmak için gerekli bilgi ağına erişememeleri, teknolojik ve sosyolojik değişimlere uyum sağlama kapasitelerinin sınırlanması işgücüne katılım oranlarının düşmesine neden olmaktadır. Böylece Türkiye'de kadınlar için çoklukla esnek çalışma, girişimcilik gibi sermaye ve patriyarka arasındaki anlaşmayla uyumlu olan istihdam biçimleri teşvik edilmektedir (Toksöz, 2011: 264). Bu noktada esnek çalışma ve kadın girişimciliği aynı paradigmanın parçaları olarak düşünülmelidir. $O$ halde, bu paradigmayı nicel olarak görebilmek için bazı sayısal verilerin paylaşılması yerinde olacaktır.

Öncelikle kadın girişimciliğiyle ilgili araştırmalarda, girişimciliğin teşvik edilmesiyle kadınların işgücüne katılımının artacağı ileri sürülmektedir (Ahl, 2006: 15; Bliss ve Garratt, 200; Dutta ve Mallick, 2018: 403). ILOSTAT'1n (2020b) y1lı verilerine göre de dünya genelinde 15 yaş üzeri istihdamın yüzde 61,5'ini erkekler, yüzde 38,5'ini kadınlar oluşturmaktadır. Toplam istihdamın yüzde 53,4'ü ücretli, yüzde 2,6's1 işveren, yüzde 34,6'sı kendi hesabına çalışan ve yüzde 9,4'ü ücretsiz aile işçisidir. ILOSTAT’’n 2019 yllı Türkiye verilerine göre istihdamın yüzde 68,5’ini ücretliler, yüzde 4,5'ini işverenler, yüzde 16,8'ini kendi hesabına çalışanlar ve yüzde 10,2'sini ücretsiz aile işçileri oluşturmaktadır. İlgili veriler, Türkiye'nin ücretli çalışanlar açısından dünya genelinin üzerinde bir orana sahip olduğunu, diğer taraftan kendi hesabına çalışanların oranının dünya ortalamasının oldukça altında kaldığını göstermektedir.

Erkeklerin işteki durumuna bakıldığında; dünyada istihdam edilen erkeklerin yüzde 52,5'inin ücretli, yüzde 3,4'ünün işveren, yüzde 38,4'ünün kendi hesabina çalışan ve yüzde 5,7'sinin ücretsiz aile işçisi olduğu görülmektedir. Kadınlarda ise bu oranlar sirasiyla yüzde 54,7 , yüzde 1,4 , yüzde 28,5 ve yüzde $15,4^{\prime}$ tür. Kadın işverenlerin ve kendi hesabına çalışanların oranı, erkeklere göre düşükken ücretsiz aile işçisi oranının yüksekliği oldukça belirgindir. Türkiye'de ise ücretlilerin sayısı dünya ortalamasının bir hayli üzerindedir. Toplam istihdam içinde erkekler en fazla, yüzde 69,3 oranıyla ücretliler kategorisinde yer almaktadır. Bu oran, kadınlarda da erkeklere benzer şekilde yüzde 66,8 düzeyindedir. Erkek işveren oranı (yüzde 5,9)

(https://www.kagider.org/kurumsal/kagider-hakkinda). Ayrıca Türkiye'de bazı bankalar girişimciliği desteklemek amacıyla kadınlara geri ödemesiz kredi olanakları sunmaktadır (Akyüz ve Kılınç Savrul 2016: 179). 
ise kadın işveren oranından (yüzde 1,5) oldukça yüksektir. Kendi hesabına çalışanlar açısından da cinsiyetler arasında eşitsizlikler bulunmaktadır. Kendi hesabına çalışan erkeklerin oranı yüzde 20,5 iken, kadınlarda bu oran yüzde 9'dur. Diğer taraftan ücretsiz aile işçisi kadınların oranı (yüzde 22,7) erkeklere göre (yüzde 4,4) çok daha yüksektir. Bu veriler, kadınların dünyada ve Türkiye'de ücretli veya ücretsiz aile işçisi statüsünde daha yoğun bir şekilde yer aldığını ortaya koymaktadır. Türkiye'de ataerkil kültürel kodlar ücretsiz aile işçisi kadınların oranının dünyadaki eğilime göre oldukça fazla olması sonucunu yaratmaktadır. Böylelikle işveren veya kendi hesabına çalışan statülerini içeren girişimcilik, kadınların erkeklere göre daha az yönelebildiği bir alan olarak karşımıza çıkmaktadır. İstihdam statülerinin cinsiyete göre dağılımına bakıldığında bu tablo daha net olarak gözükmektedir.

ILOSTAT'ın (2020a) 2020 y1lı verilerine göre dünya genelinde ücretlilerin yüzde 60,5'ini erkekler, yüzde 39,5'ini kadınlar; işverenlerin yüzde 79,5'ini erkekler, yüzde 20,5'ini kadınlar; kendi hesabına çalışanların yüzde 68,2'sini erkekler, yüzde 31,8'ini kadınlar ve ücretsiz aile işçilerinin yüzde 37,1'ini erkekler, yüzde 62,9'unu kadınlar oluşturmaktadır. Türkiye'de ise ücretlilerin yüzde 68,6'sını erkekler, yüzde 31.4'ünü kadınlar; işverenlerin yüzde 89,5'ini erkekler, yüzde 10,5'ini kadınlar; kendi hesabına çalışanların yüzde 82,7'sini erkekler, yüzde 17,3'ünü kadınlar ve ücretsiz aile işçilerinin yüzde 28,3 'ünü erkekler, yüzde $71,1^{\prime}$ 'ini kadınlar oluşturmaktadır (ILOSTAT, 2019). Tüm bu veriler, ataerkil toplumsal normlar çerçevesinde işgücü piyasasındaki toplumsal cinsiyet eşitsizliklerinin boyutlarını göstermektedir.

Girişimci kadınlar, kendi hesabına çalışan veya işveren statüsünde yer alabilmektedir. Kadın girişimciliğiyle ilişkiselliği açısından kadın işverenlere ve kendi hesabına çalışanlara dair sayısal veriler Tablo-1 ve Tablo-2'den izlenebilir.

Tablo 1: Toplam İşveren Sayısı İçerisindeki Kadın İşveren Oranı (\%), (2000, 2010, 2020)

\begin{tabular}{|l|l|l|l|}
\hline Ülke Gelir Gruplar1 ve Türkiye & $\mathbf{2 0 0 0}$ & $\mathbf{2 0 1 0}$ & $\mathbf{2 0 2 0}$ \\
\hline Dünya Ortalaması & 19 & 31 & 20 \\
\hline Düşük Gelirli Ülkeler & 20 & 22 & 24 \\
\hline Düşük-Orta Gelirli Ülkeler & 14 & 14 & 11 \\
\hline Üst-Orta Gelirli Ülkeler & 18 & 20 & 22 \\
\hline Yüksek Gelirli Ülkeler & 23 & 24 & 27 \\
\hline Türkiye25 & 5,4 & 7,1 & 10,5 \\
\hline
\end{tabular}

Kaynak: ILOSTAT verileri çerçevesinde yazarlar tarafından oluşturulmuştur.

25 ILOSTAT sisteminde Türkiye ile ilgili son veriler 2019 yllına aittir. Dolayısıyla dünya geneli açısından 2020 yllının referans alındığı verilere dair analizlerde, Türkiye'nin 2019 yllina ait verileri esas alınmaktadır. 
Tablo-1'e göre 2020 yll itibariyle dünya genelinde kadın işverenlerin sayısı, erkeklerin yüzde 20'sine tekabül etmektedir. Türkiye'de 2019 yllında kadınların toplam işverenler içindeki payı ise sadece yüzde 9'dur (ILOSTAT, 2021). Bu oran 2010 yilında yüzde 7,1 iken 2000 yllında yüzde 5,4'tür. Kadınların toplam işverenler içindeki payının düşük olduğu diğer ülkeler arasında Pakistan (yüzde 2), Mısır (yüzde 5) ve İran (yüzde 6) yer almaktadır. Öte yandan yarı-çevre ülkeler arasında yer alan Malezya (yüzde 16), Endonezya (yüzde 20) ve Meksika'daki (yüzde 20) oranlar ise Türkiye'deki kadın işveren oranının üzerindedir. Sosyal refah devletleri olan İsveç, Norveç ve Finlandiya'da bu oranlar sirasiyla yüzde 22, 23 ve 24'tür. Bu ülkeleri yüzde 25 ile 30 arasında farklılaşan oranlarda Portekiz, İspanya ve İtalya gibi Akdeniz ülkeleri takip etmektedir. Toplam işverenler içinde kadınların oranının en yüksek olduğu ülkeler ise yüzde 39 ile Azerbaycan, yüzde 33 ile Yeni Zelanda ve yüzde 32 ile Ukrayna'dır. Tüm bu nicel veriler, yoksul ülkelerdeki patriyarkal kapitalist formasyonda kadınlanın yoksullaştırıcı süreçlerden, gelişmiş ya da gelişmekte olan ülkelere göre çok daha yoğun bir biçimde etkilendiklerini ve sermayeye erişimlerinin erkeklere oranla ciddi ölçüde sınırlı olduğunu göstermektedir.

Kadın işveren sayısının toplam işveren içindeki oranının yıllara göre değişimine bakıldığında, anlamlı bir gelişme olmadığı yine Tablo 1'den anlaşılmaktadır. Türkiye'nin yüzde 9'luk oranla dünya sıralamasının en alt basamaklarında yer alması, ücretli çalışanların yanı sıra işverenler açısından da toplumsal cinsiyet eşitliğinin bulunmadığının işaretidir. Böylelikle ücretli çalışma kategorisinde kadınların emek süreçlerine katılımının düşük oranlarının yanı sıra toplumsal sınıflar arasında sosyal hareketliliği sağlayabilecek olan girişimcilik pratikleri de Türkiye'de patriyarkal kapitalizmin bariyerlerine takılmaktadır.

Kendi hesabına çalışan kadınların, toplam kendi hesabına çalışanlara oranı ise Tablo 2'den izlenebilir.

Tablo 2: Kendi Hesabına Çalışan Kadınların Toplam Kendi Hesabına Çalışanlara Oran1 (\%), (2000, 2010, 2020)

\begin{tabular}{|l|l|l|l|}
\hline Ülke Gelir Gruplar1 & $\mathbf{2 0 0 0}$ & $\mathbf{2 0 1 0}$ & $\mathbf{2 0 2 0}$ \\
\hline Dünya Ortalaması & 38 & 38 & 37 \\
\hline Düşük Gelirli Ülkeler & 46 & 46 & 46 \\
\hline Düşük-Orta Gelirli Ülkeler & 33 & 32 & 30 \\
\hline Üst-Orta Gelirli Ülkeler & 41 & 42 & 42 \\
\hline Yüksek Gelirli Ülkeler & 36 & 34 & 35 \\
\hline Türkiye26 & 14 & 18,5 & 17,3 \\
\hline
\end{tabular}

Kaynak: ILOSTAT verileri çerçevesinde yazarlar tarafindan oluşturulmuştur.

${ }^{26}$ ILOSTAT sisteminde Türkiye ile ilgili son veriler 2019 yllina aittir. Bu yüzden dünya geneli açısından 2020 ylının referans alındığı verilere dair analizlerde, Türkiye'nin 2019 yilına ait verileri esas alınmaktadır. 
Tablo 2'ye göre kadınların toplam kendi hesabına çalışanlar içindeki payı, dünyadaki hiçbir gelir grubundaki ülkede anlamlı bir artış göstermemiştir. Tablo 1 ve 2 birlikte değerlendirildiğinde, kadınların hem işveren hem de kendi hesabına çalışan kategorisinde erkeklerden daha düşük bir yoğunluğa sahip olduğu fark edilmektedir. Kendi hesabına çalışan kadınların payının en yüksek olduğu ülkeler düşük gelirli grupta yer alan ülkelerdir. Bu gerçekliğin söz konusu ülkelerdeki mikro kredi uygulamalarından kaynaklandığı ileri sürülebilir.

Toplam girişimciler içinde kadınların kendi hesabına çalışan kategorisinde yoğunlaştıklarını ifade etmek mümkündür. Dünya ortalaması itibariyle 2020 yılında toplam girişimcilerin yüzde 20'si ve toplam kendi hesabına çalışanların yüzde 37'si kadınlardan oluşmaktadır. Böylelikle kadın girişimciler düşük sermayeli işlerde daha fazla yoğunlaşmaktadır. ${ }^{27} \mathrm{AB}$ üyesi ülkelerde ise toplam istihdam içinde kendi hesabına çalışma oranı, dünya ortalamasının büyük oranda altında kalmaktadır. AB üyesi ülkelerde ortalama kendi hesabına çalışma oranı 2007 yllında yüzde 15,4 iken, bu oran 2020 yllinda yüzde 13,5’e gerilemiştir (EUROSTAT, 2020).

Tablo 3: Avrupa Ülkelerinde Kadın İstihdamı İçinde Kendi Hesabına Çalışanların Oran1 (\%) (2020)

\begin{tabular}{|l|l|l|l|}
\hline Ülke & Oran & Ülke & Oran \\
\hline İsveç & 5 & Portekiz & 10,5 \\
\hline Danimarka & 5,2 & Litvanya & 10,6 \\
\hline Almanya & 5,7 & Türkiye & 10,7 \\
\hline Bulgaristan & 6,7 & İspanya & 11,3 \\
\hline Fransa & 8,5 & Çek Cumhuriyeti & 11,6 \\
\hline Romanya & 9,3 & Polonya & 12,3 \\
\hline AB Ortalaması & 9,6 & İtalya & 14,6 \\
\hline Belçika & 10,1 & Yunanistan & 21,2 \\
\hline
\end{tabular}

Kaynak: EUROSTAT verileri çerçevesinde yazarlar tarafindan oluşturulmuştur.

Tablo 3'teki verilere göre kadın istihdamında kendi hesabına çalışanların oranının en düşük olduğu ülkeler İskandinav ülkeleri ve sanayileşmiş Kıta Avrupası ülkeleridir. Eski sosyalist rejimler arasında yer alan Bulgaristan'da da bu oranın

${ }^{27}$ İstihdam statüleri içinde yer alan kendi hesabına çalışan ile işveren arasında önemli bir ayrım bulunmaktadır. İşveren, yanında işçi çalışıran kimseyi tarif ederken kendi hesabına çalışanlar sermayesinin yanında bedeni veya zihinsel emeğini de arz etmektedir. Tüm işverenler, ileri teknoloji veya yüksek sermayeli işlerde yer almamakla birlikte; ücretli çalışanları istihdam etmeleri nedeniyle kendi hesabına çalışanlara oranla daha yüksek sermayeli işlerde yoğunlaşmaktadır. Kendi hesabına çalş̧anların işletme ölçekleri ise işverenlerden daha düşük düzeylerde kalmaktadır. 
düşük olduğu göze çarpmaktadır. Kadınların toplam istihdamı içinde kendi hesabına çalışma oranının en yüksek olduğu coğrafya ise Akdeniz ülkeleridir. Avrupa sınırlarındaki en yüksek oran yüzde 21,2 ile Yunanistan olup Türkiye de Akdeniz ülkelerine yakın bir orana sahiptir. Avrupa'nın küreselleşme ve esnek üretim zamanları öncesindeki sosyal refah devleti mirasına sahip olan ve günümüzde refah politikalarını büyük ölçüde sürdüren İsveç ve Danimarka gibi ülkelerde işgücü piyasalarında kadınların ücretli istihdama daha yüksek oranlarda katılması, bu ülkeleri diğerlerinden farklılaştırmaktadır.

Türkiye'de kadın girişimciliğine dair etkinliklerin ve girişimciliğin ele alınma biçimlerinin değerlendirilmesi bağlamında ise öncelikle WES'in temsilcisi olan KOSGEB'in, kadın girişimciliğini teşvik eden uygulamalar yürüttüğü belirtilmelidir. Bunlar arasında girişimcilik eğitimi, rehberlik, danışmanlık hizmetleri ve finansman destekleri bulunmaktadır. ISSKUR ise, Türkiye'de aktif istihdam politikası araçları kapsamında girişimcilik eğitimleri düzenlemektedir. İŞKUR'un girişimcilik eğitimlerine ilişkin son verileri 2019 yllını kapsayan yıllık istatistiklerine yansımıştır. Buna göre girişimcilik eğitim programından faydalanan toplam 41 bin 107 kişinin 21 bin 702'si erkek, 19 bin 405'i kadındır. ISSKUR, aktif istihdam politikası aracı olarak girişimcilik eğitimlerinin yanı sıra işbaşı eğitim programları gibi araçları da kullanmaktadır. Kurumun tüm aktif istihdam programlarından yararlanan kişi sayısı 568 bin 420 iken, bu kişilerin 266 bin 476's1 erkek, 301 bin 944’ü ise kadındır (ISSKUR, 2019). Aktif istihdam programlarından yararlanmada kadınların sayıca fazla olduğu, ancak girişimcilik eğitim programlarından erkeklerin görece daha fazla yararlandığı göze çarpmaktadır. Bu veriler, kurumsal politikalardan yararlanma açısından kadınlar adına olumlu bir gelişmeyi yansıtmakla birlikte, Türkiye'de hâlen girişimciliğin eril bir kategori olduğunu da göstermektedir.

ILO ve İŞKUR ortaklı̆̆ında gerçekleştirilen "Kadınlar İçin Daha Çok ve Daha İyi İşler: Türkiye'de İnsana Yakışır İş İçin Kadınların Güçlendirilmesi Projesi" kadın girişimciliğini teşvik eden uygulamalar arasında yer almaktadır. 20132018 yılları arasında süren projenin finansman kaynağı İsveç Uluslararası Kalkınma İşbirliği Ajansı (SIDA) olmuştur. Bu projeyle, kadınların ekonomik ve sosyal alanda güçlendirilmesi doğrultusunda, aktif işgücü piyasası politikalarına toplumsal cinsiyet eşitliği perspektifi kazandırılması hedeflenmiştir. Kamu kurum ve kuruluşları, üniversiteler, sendikalar ve sivil toplum örgütlerinin paydaş olduğu projeyle ulaşılmak istenen temel sonuç toplumsal cinsiyet eșitliğine duyarlı kadın istihdamı politikalarının geliştirilmesidir. Pilot il olarak belirlenen İstanbul, Ankara, Bursa ve Konya'da yerel düzeyde etkinliklerde bulunulmuştur. Proje kapsamında mesleki eğitim ve temel yaşam becerilerinin geliştirilmesi, toplumsal cinsiyet eşitliği ve çalışma standartlarında eşitlik gibi konularda eğitimler düzenlenmiştir. Buna ek olarak İSKUR'a kayıtlı 200 kadına girişimcilik eğitimi verilmiştir. ${ }^{28}$

${ }^{28}$ ILO-İŞKUR işbirliğinde gerçekleştirilen projenin detayları için bkz.

http://esitizberaberiz.org/ (15.05.2021). 
2018 verilerine göre Türkiye'de kadın girişimciliğinin yoğunlaştığ alan, üçüncül sektör kategorisinde değerlendirilen hizmetler sektörüdür. Hizmetler sektöründe kadın girişimcilerin oranı yüzde 73 iken; sanayi, inşaat, nakliye, imalat vb. gibi alanları kapsayan ikincil sektörde yüzde 22,1 ve tarım, hayvancilık, ormancillk ve madenciliği kapsayan birincil sektörde yüzde 4,9'dur (Karadeniz, 2019: 33). Türkiye'de kadın girişimciliğine dair program ve projelerin hanehalkı yoksulluğunu giderme, işsizlikle mücadele etme ve işgücüne katılım oranlarını artırma, kadınları güçlendirme ve toplumsal cinsiyet eşitliğini sağlama gibi bileşenleri bulunsa da (Ecevit, 2007: 47); ekonomik büyüme ve kalkınmanın sağlanmasinda araçsal olarak görülen bu stratejilerin geliştirilmesinde, Türkiye'nin Avrupa Birliği kriterlerine uyum süreci, Dünya Bankası ve Birleşmiş Milletler gibi uluslararası kuruluşların izledikleri politikaların güdümünde olması önemli rol oynamıştır. Üstelik tutarlı bir kadın istihdamı politikasının bulunmaması nedeniyle Türkiye'de kadın girişimciliği farklı yaklaşımlarla biçimlenen politikalar izlenerek ele alınmamıştır (2007: 47). Birçok kuruluş ekseninde biçimlenen ve arz yönlü bir karaktere sahip olan uygulamalarla (Sallan Gül ve Altındal, 2016: 1367), kadın girişimciliğinin asli bir amaç olmak yerine kadınların işgücüne katılım oranlarının artırılması yönündeki politikaların başarısızlıklarını bertaraf etmek için izlenen bir politika arac1 haline geldiği söylenebilir (Ecevit, 2007: 39-42). Türkiye'de kadın girişimciliği bağlamında var olan perspektif birçok ülkede olduğu gibi neoliberalizmin etkisi altındadır. Bu kapsamda kadınların iş sahibi olma süreçlerinde bağımsızlık kazanmalarının amaçlanmasından ziyade küçük işletmelerde kendi hesabına çalışmaya teşvik edilmesi söz konusu olmuş, bu yaklaşım ve uygulamalar mikro krediler ve girişimci eğitimleriyle desteklenmiştir (Sallan Gül ve Altındal, 2016: 1370). Tüm bunlara ek olarak kadın girişimciliği bütünsellikten ziyade parçalı ve eşgüdümsüz projelerle desteklenmiş ve bir politika alanı olmaktan uzaklaşmıştır (Ecevit, 2007: 39-40). Bu noktada küresel ekonomipolitiğin ürettiği metalaşma süreçlerine rağmen kadın girişimciliği olgusu başarılı uygulamalar aracilığıyla kadınların ekonomik, toplumsal, siyasal ve sivil haklara dair özgürlüklerine kapı aralayabilmektedir. Fakat girişimciliğin politize edilmeye açık olan ve ücretli emeği ikincilleştirerek kadınları serbest piyasa ilişkilerine bağlayan bir küresel manevra alanı olduğu da düşünülebilir.

Her ne kadar kirsal ve kentsel alanlarda girişimciliğin toplumsal cinsiyet eşitsizliklerini azaltacağı, kadınların kamusal alana katılma süreçlerini hızlandırarak onları yoksulluktan kurtaracağ1 varsayımları giderek popüler hale gelse de; bu noktada pratik ihtiyaçlar/stratejik ihtiyaçlar ayrımının göz önünde bulundurulması gerekmektedir. Kadın girişimciliği, ilgili literatürün bir kısmında ve kimi pratik uygulamalar nezdinde, kadınların ev-iş dengesini kurabilmelerini sağladığ1 ve hane içi yükümlülüklerini yerine getirmelerine engel olmadığı gerekçesiyle fazlaca olumlanmış gözükmektedir. Böylelikle bu şartlarda girişimci olmanın doğal bir biçimde ve verili olarak kadınların yaşamlarını kolaylaştıracağı ileri sürülmüştür. Fakat bu yaklaşımda kadınların hane içi yükümlülükleri parantez içinde tutularak, 
bağımsız bir çalışan kadın kurgusunun yapılmadığı görülmektedir. Bir başka deyişle güçlendirme yaklaşımı ekseninde değerlendirilmeyen girişimcilik pratiklerinde, kadınlar her zaman hane içi yükümlülüklerden sorumlu olacaklar ve patriyarkal dizge istikrarlı ve tavizsiz bir biçimde devam edecek, kadınlara sağlanan iş alternatifleri ancak onların hane içi yükümlülüklerini yerine getirmelerine engel olmadığ ölçüde uygulanabilir olacaktır.

\section{Sonuç}

Küreselleşme süreciyle birlikte özellikle emek süreçlerindeki belirsizlik ve güvencesizlikler, sosyal korumanın azalmasına ya da yok olmasına, işsizliğin, kayıtdışıllı̆ı̆n, atipik çalışmanın yaygınlaşmasına ve yeni yoksulluğun ortaya çıkmasına neden olmuştur. Bu ekonomi-politik iklimde sosyal refah devletinin önemsendiği yıllarda benimsenen sosyal politika uygulamalarının terk edilmesi, küresel meta zincirlerinin tüm dünya coğrafyasına yayılması, esnek çalışmanın kâr maksimizasyonu içeren pratiklerinin normalleşmesi, hizmetler sektörünün genişlemesi, düşük ücretli, yarı zamanlı istihdam biçimlerinin ve girişimcilik uygulamalarının yaygınlaşması yeni kapitalizmin görünümleridir.

Genel itibariyle sosyal politikanın sürgüne gönderildiği neoliberalizm yıllarında var olan sosyal problemlerin çözümüne dair geliştirilen düşünceler ise büyük oranda fiksiyonel bir içeriktedir. Bilindiği gibi kalkınma ve kadın girişimciliği ilişkisi bağlamında sosyolojik sorunlara çözüm üretmeye çalışan, birbirinden farklılaşan yaklaşımlar bulunmaktadır. Bunların çoğu yoksulluğu yeniden üreten politikalar olarak gözükmektedir. Tam da bu nedenle mevcut bakış açıları içinde güçlendirme yaklaşımı, kadınların toplumsal alanda güçlenmesini sağlayacak teorik ve pratik bir perspektif içermesi ve kadınlanı özgürleştirme potansiyeli taşıması nedeniyle tercih edilebilir bir niteliğe sahiptir. Fakat yine de kapitalist sosyoekonomik formasyonun güvencesizlik ve belirsizlik içeren sosyolojisinde sözü edilen yaklaşım da büyük oranda gelir eşitsizlikleri ve sosyal sınıf farkları açısından toplumsal değil bireysel çözümler üretmektedir. Bunun nedeni kapitalizmin değişken, istikrarsız piyasa koşullarının taşıdığı riskler nedeniyle bireysel girişimcilik süreçlerinin başarısızlıkla sonuçlanabilmesidir.

Kadın girişimciliği olgusu bir yandan da küreselleşen piyasa ekonomilerinde merkez-çevre ülkeler karşıtllğı ekseninde özellikle azgelişmiş ve gelişmekte olan ülkeler için Dünya Bankası, Uluslararası Para Fonu gibi uluslararası kuruluşların ve Avrupa Birliği’nin yoksulluk ve kadın işsizliğine yönelik geliştirdikleri bir politika olmuştur. Bu ülkeler arasında Hindistan, Bangladeş gibi yoksul ülkeler ve bazı Afrika ülkeleri yer almaktadır. Uluslararası kuruluşlar araciluğılla hayata geçirilen kadın girişimciliği faaliyetleri, mikro kredi uygulamaları aracıllğıyla yürütülmüş̧; gelir ve kredi olanaklarına erişimi sınırlı olan dezavantajlı durumdaki kadınlara kredi sağlanarak kendi işlerini/girişimlerini kurmaları teşvik edilmiştir. Mikro kredi uygulamalarının ekonomik ve toplumsal kalkınmada gecikmiş, yar1-çevre ve çevre ülkelerde yaygın olması ise 
küresel kapitalizmin ya da Sennett’in (2015) “yeni kapitalizm” olarak adlandırdı̆ğ küresel işbölümünün ekonomi-politik işleyişini deşifre etmektedir.

Tüm bu verili ekonomi-politik koşullar bağlamında, esasen kadın işsizliği ve yoksulluğuyla mücadele etmenin önemli bir aracı toplumsal cinsiyet eşitliğinin ana akımlaştırılması, başka bir deyişle farklı politika alanlarına aktarılmasıdır. İstihdam ve eğitim politikalarının işleyişinin rotası bu çerçevede önemli bir nirengi noktasıdır. Kadınların pratik ihtiyaçlarına cevap verebilecek yaklaşımlar geliştirilerek toplumsal cinsiyete dayalı hane içi rollerini yeniden üretecek biçimde değil, işgücü piyasalarına katılmalarını ve sosyal bariyerleri aşmalarını sağlayabilecek politikalara gereksinim duyulmaktadır. Bir yandan da yoksul kadınların patriyarka ve üretim ilişkilerince sınırlanmış ve hane içindeki gelirin eşitsiz dağılımına yansıyan sosyal konumları göz önüne alınmalıdır.

Kadın girişimciliği, kadınların güçlenmelerini ve ekonomik firsatlara erişebilmelerini kısmen sağlasa da uygulanan proje ve programlar kapsamında örtük olarak, kadınların kazandıkları gelirin yine doğrudan eşlerine ya da ailelerine aktarılacağı varsayımı üzerinden biçimlenmiştir. Bu noktada girişimcilik pratikleri, yoksulluğun yapısal faktörleriyle mücadele etmek yerine, pratik ve yüzeysel bir çözüm olarak uygulanmaktadır. Aksine girişimcilik uygulamaları bireyleri sınıfsal açıdan küçük işyeri sahipliği itibariyle görece orta-üst sınıflara doğru yükseltme potansiyeline de sahiptir. Öte yandan yeni kapitalizmde piyasa riskleri nedeniyle iş kurma pratiklerindeki başarısızlıklar, bireyleri bir borç rejimine de sürükleyebilecektir. Bu çelişki nedeniyle girişimcilik uygulamaları riskler içeren düalistik bir yapıya sahiptir. Özellikle Beck (1992) tarafindan "risk toplumu" olarak kavramsallaşturlan, günümüzün esnek çalışma uygulamalarının içerdiği riskler girişimcilik pratikleri bağlamında da geçerlidir.

Kadın girişimciliği uygulamalarının Türkiye'deki yansımaları da sözü edilen eğilimlere koşut politikalarla gelişmiştir. 1980’lerden itibaren uluslararası kuruluşların yönlendirmesiyle kadın girişimciliğine dair faaliyetlerde, projelerde ve programlarda adeta bir patlama yaşanmıştır. Kadınlara sağlanan girişimcilik olanak ve firsatları birçok kadını gelir getirici bir iş sahibi yapsa da kadın girişimciliği faaliyetlerinin tam istihdam politikası yerine benimsenmesinin, kadın yoksulluğu ve işsizliğinin yapısal faktörleriyle mücadele etmekten uzak olduğu söylenebilir. Kadın girişimciliğiyle ilgili bir diğer sorun kadınların geleneksel olarak toplum içinde konumlandırıldıkları faaliyet alanlarına yönlendirilmeleridir. Bilindiği gibi kadının aile ve hane içi yükümlülükler bağlamında sorumlu tutulduğu geleneksel roller, patriyarkal sistemin tarihsel ve yapisal etkisiyle fazlaca sorgulanmayan bir sosyal ilişki kurma, kültürlenme ve toplumsallaşma biçimi olarak benimsenmiştir. $O$ halde günümüz çalışma ilişkilerinde esnek çalışmanın kutsandığ1 ataerkil kapitalizm tarafından biçimlendirilen girişimcilik firsatları, patriyarkal bariyerleri besleyerek toplumsal cinsiyete dayalı rolleri yeniden üretme potansiyeline sahiptir.

Türkiye işgücü piyasasındaki mevcut tabakalı ve cinsiyetçi yapı, kadınların işgücü piyasasına katılma oranlarının düşük olmasının yanı sıra katılanların ancak düşük gelirli ve güvencesiz işlerde çalışabilmelerine neden olmaktadır. Bu noktada 
yoksulluğu ve emeğin feminizasyonu süreçlerini üreten yapısal etmenlerle mücadele etmek yerine geçici bir çözüm sunabilen girişimcilik faaliyetlerine odaklanmak, bir sosyal politikasızlı anlamına gelebilmektedir. Nitekim postmodern küresel zamanlarda gelir dağılımı adaletsizliklerinin yarattığı eşitsizlikler ve toplumsal hareketliliğin azalmasıyla birlikte ortaya çıan bunalımlar, girişimcilik etkinliklerinin yaygınlaşmasının engelleyemeyeceği sosyal dışlanma ve yabancılaşma gibi toplumsal sorunların farklılaşan boyutlarını üretmektedir.

\section{Beyan}

"Güçlendirme ve Toplumsal Cinsiyet Rolleri İkileminde Kadın Girişimciliğ̣ı" başlıklı makale kapsamında herhangi bir kurum veya kişi ile çıkar çatışması bulunmamakta olup, yazarlar arasında da çıkar çatışması yoktur.

Aslıcan Kalfa Topateş, Hakan Topateş, Erkan Kıdak tarafindan kaleme alınan "Güçlendirme ve Toplumsal Cinsiyet Rolleri İkileminde Kadın Girişimciliğı" başlıklı makalede, yazarların katkı oranları eşittir. 


\section{KAYNAKÇA}

Aalito, L. (2008) "Entrepreneurship in Organization: Gender and Social Capital", Kyrö, P. ve Sundin, E. (ed.) in Women Entrepreneurship and Social

Capital: A Dialogue and Construction, Koge, Portland, Abingdon: Copenhagen Business School Press, 23-39.

Adorno, T. ve Horkheimer, M. (2013) Teori ve Pratik Üzerine Bir Tartışma (çev. O. K1lıç), İstanbul: Metis Yayınları.

Ahl, H. (2006) "Why Research on Women Entrepreneurs Needs New Directions", Entrepreneurship Theory and Practice, 30(5), 595-621.

Akder, H. (2003) "Rural Women and Poverty", in Bridging the Gender Gap in Turkey: A Milestone Towards Faster Socio-economic Development and Poverty Reduction, Poverty Reduction and Economic Management Unit Europe and Central Asia Region, 119-141.

Akyüz, D. ve Kılınç Savrul, B. (2016) "Türkiye Ekonomisinde Kadın Girişimcilerin Mevcut Durumu ve Geliştirilmesine Yönelik Çözüm Önerileri”, Girişimcilik ve Kalkınma Dergisi, 11(1), 1361-1377.

Arendt, H. (2014) Totalitarizm (çev. İ. Serin), İstanbul: İletişim Yayınları.

Arrighi, G. (2016) Uzun Yirminci Yüzyıl: Para, Güç ve Çağımızın Kökenleri (çev.

R. Boztemur), Ankara: İmge Kitabevi.

Arruzza, C., Bhattacharya, T. ve Fraser, N. (2019) \%99 için Feminizm: Bir Manifesto (çev. U. Özmakas), İstanbul: Sel Yayıncilık.

Bauman, Z. (1999) Çalışma, Tüketicilik ve Yeni Yoksullar (çev. Ü. Öktem), İstanbul: Sarmal Yayınevi.

Beck, U. (1992) Risk Society: Towards a New Modernity, London: SAGE Publications.

Beneria, L. (2003) "Paid and Unpaid Labour: Meanings and Debates", Beneria, L. (ed.) in Gender, Development and Globalization, New York, London: Routledge, 131-160.

Bliss, R. T. and Garratt, N. L. (2001) "Supporting Women Entrepreneurs in Transitioning Economies", Journal of Small Business Management, 39(4), 336-344.

Braudel, F. (2015) Kapitalizmin Kısa Tarihi (çev. İ. Yerguz), İstanbul: Say Yayınları. Bruni, A., Gherardi, S. and Poggio, B. (2005) Gender and Entrepreneurship: An Ethnographical Approach, New York: Routledge.

Butler, J. E. (2005) "New Perspectives on Women Entrepreneurs: An Introduction", Butler, J. E. (ed.) in New Perspectives on Women Entrepreneurs, Greenwich: Information Age Publishing, 11-15.

Chossudovsky, M. (1999) Yoksulluğun Küreselleşmesi (çev. N. Domaniç), İstanbul: Çivi Yazıları.

Coughelin, J. H. and Thomas, A. T. (2002) The Rise of Women Enterepreneurs: People, Processes and Global Trends, Westford, Connecticut, London: Quorum Books. 
De Bruin, A., Brush, C. G. and Welter, F. (2006) "Introduction to the Special Issue: Towards Building Cumulative Knowledge on Women's Entrepreneurship", Entrepreneurship Theory and Practice, September, 585-593.

De Vita, L., Mari, M., and Poggesi, S. (2014) "Women Entrepreneurs in and from Developing Countries: Evidences from the Literature", European Management Journal, 32(3), 451-460.

Derin Yoksulluk Ağ1 (2020) Pandemi Döneminde Derin Yoksulluk ve Haklara Erișim Arasttrmast-Yerel Yönetimlere Kriz. Dönemi Sosyal Destek Programlar İcin Öneriler, https://derinyoksullukagi.org/raporlar/pandemi-doneminde-derin-

yoksulluk-ve-haklara-erisim-arastirmasi-yerel-yonetimlere-kriz-donemisosyal-destek-programlari-icin-oneriler/ (06.07.2021).

Dutta, N. and Mallick, S. (2018) "Enabling Women Entrepreneurs: Exploring Factors that Mitigate the Negative Impact of Fertility Rates on Female Entrepreneurship", Kyklos, 71(3), 402-432.

Ecevit, Y. (2007) Türkiye'de Kadın Girişimciliğine Eleştirel Bir Yaklaşım, Ankara: Uluslararası Çalışma Ofisi.

Ekiz Gökmen, Ç. ve Gökovalı, U. (2016) "Hane İçine Gizlenen Kadın Yoksulluğu: Muğla-Mardin Örneği”, ODTÜ Gelişme Dergisi, 43(1), 157-190.

European Commission (2021) COSME-Europe's Programme for Small and Mediumsized Enterprises, https://ec.europa.eu/growth/smes/cosme/supportingentrepreneurs_en, (07.06.2021).

EUROSTAT (2020) Percentage of Self-employed by Sex, Age Groups and Household Composition,

https://ec.europa.eu/eurostat/databrowser/view/lfst_hhsety/default/table ?lang=en, (06.06.2021).

Fairclough, N. C. (2012) "How do Social Welfare and Support Systems Influence the Attitudes of Female Entrepreneurs Towards Risk and Options?", Hughes, K. and Jennings, J. (eds.) in Global Women's Entrepreneurship Research: Diverse Settings, Questions and Approaches, Northampton: Edward Elgar Publishing, 95-144.

Fernando, J. L. (1997) "Nongovernmental Organizations, Micro-Credit, and Empowerment of Women," The Annals of the American Academy of Political and Social Science, 554, 150-177.

Gökovalı, U. ve Danışman, A. (2010) "Feminization of Poverty: Does it Really Exist in Turkey?”, New Perspectives on Turkey, 42, 179-201.

Greer, M. J. and Grene, P. G. (2003) "Feminist Theory and Entrepreneurship", Butler, J. E. (ed.) in New Perspectives on Women Entrepreneurs, Greenwich: Information Age Publishing, 1-24.

Gurnani, P. S. (2016) Women Entrepreneurship: Emerging Dimension of Entrepreneurship in India, New Delhi: Educreation Publishing.

Habermas, J. (2019) İletişimsel Eylem Kuramı (çev. M. Tüzel), İstanbul: Alfa Yayınları. 
ILO (2019) A Quantum Leap for Gender Equality: For a Better Future of Work for All, Geneva: International Labour Office.

ILO (2018) Çalışma Yaşamında Toplumsal Cinsiyet Eşitliği Eğitim Rehberi, Kadınlar İçin Daha Çok ve Daha İyi İşler: Türkiye'de İnsana Yakışır İş İçin Kadınların Güçlendirilmesi Projesi, Ankara: ILO, http://esitizberaberiz.org/wp-

content/uploads $/ 2018 / 08 / \% \mathrm{C} 3 \% 87 \mathrm{al} \% \mathrm{C} 4 \% \mathrm{~B} 1 \% \mathrm{C} 5 \% 9 \mathrm{Fma}-$ Ya\%C5\%9Fam $\%$ C4\%B1nda-Toplumsal-Cinsiyet-E $\%$ C 5\% $\%$ Fitli $\% C 4 \% 9 F i-$ E\%C4\%9Fitim-Rehberi.pdf (11.12.2021).

ILOSTAT (2019) Employment by Sex and Status in Employment, ILO Modelled Estimates, https:/ /www.ilo.org/shinyapps/bulkexplorer32/?lang=en\&segment=indica tor\&id=EAP_2WAP_SEX_AGE_RT_A (15.05.2021).

ILOSTAT (2020a) Employment by Sex and Status in Employment, ILO Modelled Estimates,

https:/ /www.ilo.org/shinyapps/bulkexplorer32/?lang=en\&segment=indica tor\&id=EAP_2WAP_SEX_AGE_RT_A (03.05.2021).

ILOSTAT (2020b) Labour Force Participation Rate by Sex and Age, https://www.ilo.org/shinyapps/bulkexplorer51/?lang=en\&segment=indica tor\&id=EAP_2WAP_SEX_AGE_RT_A, (05.06.2021).

ILOSTAT (2021) Employment by Sex and Status in Employment, ILO Modelled Estimates, https://www.ilo.org/shinyapps/bulkexplorer32/?lang=en\&segment=indica tor\&id=EAP_2WAP_SEX_AGE_RT_A (05.06.2021).

ISSKUR (2019) Istatistik Yilliklar 2019 Yillik Tablolar, https://www.iskur.gov.tr/kurumsal-bilgi/istatistikler/ (17.05.2021).

Jerinabi, U. (2007) "Empowerment of Women Through Micro Entrepreneurship", Tiwari, S. and Tiwari A. (eds.) in Women Entrepreneurship and Economic Development, New Delhi: Sarup \& Sons, 45-51.

Kandiyoti D. (1988) "Bargaining with Patriarchy", Gender \& Society, 2(3), 274290.

Karadeniz, E. E. (2019) Türkiye'de Girişimcilik ve Uluslararası Karşılaştırma, İstanbul: Yeditepe Üniversitesi Yayinevi.

Kirzner, I. M. (1985) Discovery and the Capitalist Process, Chicago and London: The University of Chicago Press.

Mackintosh, M. (1981) "Gender and Economics: The Sexual Division of Labour and the Subordination of Women", Young, K., Wolkowitz, K. C. and McCullagh, R. (eds.) in Of Marriage and the Market, London: CSE Books, 3-17.

Makombe, I. A. M. (2006) Women Entrepreneurship Development and Empowerment in Tanzania: The Case of SIDO-UNIDO-Supported Women Microentrepreneurs in the Food Processing Sector, Development Studies at the University of South Africa. 
Manolova, T. S., Brush, C. G., and Edelman, L. F. (2008) "What Do Women Entrepreneurs Want?”, Strategic Change, 17(3-4), 69-82.

McAdam, M. (2013) Female Entrepreneurship, London and New York: Routledge.

Moser, C. (1993) Gender Planning and Development: Theory, Practice and Training, London and New York: Routledge.

Munck, R. (1995) Uluslararası Emek Çalışmaları (çev. C. Aygün), Ankara: Öteki Yayinevi.

Nusbaum, M. (1999) "Women and Equality: The Capabilities Approach", International Labour Review, 138(3), 227-245.

Okpara, J. O., Halkias, D., Nwajiuba, C., Harkiolakis, N., and Caracatsanis, S. M. (2011) "Challenges Facing Women Entrepreneurs in Nigeria", Management Research Review, 32(2), 221-235.

Ostergaard, L. (1992) “Gender”, Ostergaard, L. (ed.) Gender and Development: A Practical Guide, London: Routledge, 1-10.

Pearce, D. (1978) "The Feminization of Poverty: Women, Work and Welfare", Urban \& Social Change Review, 11(1), 28-36.

Petras, J. ve Veltmeyer, H. (2006) Maskesi Düşürülen Küreselleşme (çev. Ö. Akpinar), İstanbul: Mephisto.

Rani, D. L. (1996) Women Entrepreneurs, New Delhi: A.P.H. Publishing Corporation.

Sallan Gül, S. (2005) “Türkiye’de Yoksulluğun Kadınsılaşması”, Amme İdaresi Dergisi, 38(1), 25-45.

Sallan Gül, S. ve Altındal, Y. (2016) “Türkiye'de Kadın Girişimciliğinin Serüveni: Başarı Mümkün Mü?”, Süleyman Demirel Üniversitesi İktisadi ve İdari Bilimler Fakültesi Dergisi, 21(4), 1361-1377.

Sarfaraz, L. (2017) Women's Entrepreneurship in Iran: Role Models of Growth-Oriented Iranian Women Entrepreneurs, Cham: Springer Publishing.

Schumpeter, J.A. (1934) The Theory of Economic Development, Cambridge MA: Harvard University Press.

Sen, A. (2003) "Development as Capability Expansion”, Fukuda-Parr, S. ve Shiva Kumar, A. K. (eds.) in Readings in Human Development, New Delhi and New York: Oxford University Press, 41-58.

Sennett, R. (2015) Yeni Kapitalizmin Kültürü (çev. A. Onocak), İstanbul: Ayrıntı Yayinlari.

Shukla, M. B. (2007) "Contemporary Issues in Entrepreneurship with regard to Reconstruction of Social Structure in India: A Futuristic Approach", Tiwari, S. and Tiwari A. (eds.) Women Entrepreneurship and Economic Development, New Delhi: Sarup \& Sons, 1-12.

Soysal, A. (2010) 'Türkiye'de Kadın Girişimciler: Engeller ve Firsatlar Bağlamında Bir Değerlendirme”, SBF Dergisi, 65(1), 83-114. 
Still, L. V. (2005) "The Constraints Facing Women Entering Small Business Ownership", Fielden, S. L. and Davidson, M. C. (eds.) in International Handbook of Women and Small Business Entrepreneurship, Cheltenham, Northampton: Edward Elgar Publishing, 55-66.

Şenses, F. (2004) "Neoliberal Küreselleşme Kalkınma için Bir Firsat mı, Engel mi?”, ERC Working Paper in Economic 04/09, Ankara: Middle East Technical University Research Center.

Thinker, I. (1990) "The Making of a Field: Advocates, Practitioners, and Scholars", Thinker, I. (ed.) in Persistent Inequalities: Women and World Development, New York: Oxford University Press, 27-53.

Toksöz, G. (2007) Türkiye'de Kadın İstihdamının Durumu, Ankara: Uluslararası Çalışma Örgütü.

Toksöz, G. (2011) Kalkınmada Kadın Emeği, İstanbul: Varlık Yayınları.

Toksöz, G., Özkazanç, A. ve Poyraz, B. (2001) Kadınlar, Kalkınma ve Sosyal Adalet, Ankara: A.Ü. Kadın Sorunları Araştırma ve Uygulama Merkezi.

Yıldırak, N., Gülçubuk, B., Gün, S., Olhan, E. ve Kılıç, E. (2003) Türkiye'de

Gezici ve Geçici Kadın Tarım İşçilerinin Çalışma ve Yaşam Koşulları ve Sorunları, Ankara: Tarım-İş Sendikası.

Wallerstein, I. (2014) Dünya Sistemleri Analizi-Bir Giriş (çev. E. Abadoğlu), İstanbul: Bgst Yayınları.

Wallerstein, I. (2016) Tarihsel Kapitalizm ve Kapitalist Uygarlık (çev. N. Alpay), İstanbul: Metis Yayınları.

Weber, M. (2017) Sosyoloji Yazıları (çev. T. Parla), İstanbul: Deniz Yayınları.

Whitehead A. and Bloom H. (1992) "Agriculture", Ostergaard, L. (ed.) Gender and Development: A Practical Guide, London: Routledge, 41-55.

Women's World Banking (1996) A Report, https://www.gdrc.org/icm/wind/wwbreport.html (11.12.2021).

Wood, E. M. (2018) Sınıftan Kaçı̧: Yeni 'Hakiki' Sosyalizm (çev. Ş. Alpagut), İstanbul: Yordam Yayınları.

Yetim, N. (2002) "Sosyal Sermaye Olarak Kadın Girişimciler: Mersin Örneği”, Ege Akademik Bakış, (2/2), 79-92.

Yunus, M. (1999) Yoksulluğun Bulunmadı̆̆1 Bir Dünyaya Doğru (çev. G. Şen), İstanbul: Doğan Kitapç1lik.

\section{İnternet Adresleri}

https://ec.europa.eu/growth/smes/cosme/supporting-entrepreneurs en (07.06.2021).

http://esitizberaberiz.org/ (15.05.2021). https://www.kagider.org/kurumsal/kagider-hakkinda (07.06.2021). https://www.tr.undp.org/content/turkey/tr/home/sustainable-developmentgoals.html (10.04.2021). 